\title{
The Lodin Elv Formation; a Plio-Pleistocene occurrence in Greenland
}

\author{
ROLF. W. FEYLING-HANSSEN, SVEND FUNDER and KAJ STRAND PETERSEN
}

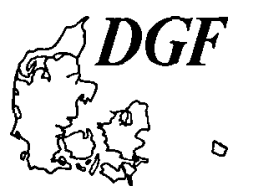

\begin{abstract}
Feyling-Hanssen, R. W., Funder, S. and Petersen, K. Strand: The Lodin Elv Formation; a Plio-Pleistocene occurrence in Greenland. Bull. geol. Soc. Denmark, vol. 31, pp. 81-106. Copenhagen, March 7th, 1983.

A new occurrence of Plio-Pleistocene marine fossiliferous sediments from Jameson Land, East Greenland, is described and named the Lodin Elv Formation. The sedimentary sequence consists of sorted sand and silt overlain by diamicton containing erratic boulders. Both units contain in situ molluscs and foraminiferal assemblages. The sediments occur as an erosional remnant of local distribution, covered by Holocene deltaic sand, and probably rest on Jurassic shale. The thickness is c. 40 metres. The formation is dated faunistically by its foraminiferal faunas, which are correlated with occurrences in the North Sea and on Baffin Island. The suggested age is supported by amino acid analyses of mollusc shells. The Lodin Elv Formation records the earliest known evidence of glaciation and arctic conditions in Greenland in post-Precambrian time.
\end{abstract}

R. W. Feyling-Hanssen, Department of Micropaleontology, Institue of Geology, University of Aarhus, 8000 Aarhus C, Denmark. S. Funder, Geological Museum, Øster Voldgade 5-7, 1350 Copenhagen K, Denmark. K. Strand Petersen, Geological Survey of Denmark, Thoravej 31, 2400 Copenhagen NV, Denmark. July 15 th, 1982.

\section{Introduction}

In 1978, during mapping of the Quaternary deposits of Jameson Land, East Greenland, a sequence containing several units of pre-Holocene unconsolidated sediments was discovered by two of us (S. Funder and K. Strand Petersen) at the mouth of Lodin Elv. The section was routinely measured and sampled. Subsequent analyses of its foreminifera (by R. W. Feyling-Hanssen) indicated a Plio-Pleistocene age for the sediments - a contention which received some support from an amino acid analysis of mollusc shells from the deposit.

These mutually independent results place the deposit within a significant gap in the Greenland fossil record, a gap which extended from the early Neogene to the late Pleistocene and includes the period during which the local environment changed from warm temperate to high arctic. For this reason we feel that the occurrence, although only poorly exposed, merits som attention. The lithology and fossil content of the deposit are described below. It is formally designated as the Lodin Elv Formation, and tentatively referred to the Upper Pliocene and lowest Pleistocene.

\section{Location, type locality and stratigraphy}

The formation occurs near the coast of northern Jameson Land and is named after Lodin Elv, the stream at which the sections have been recorded. As type locality we designate the section on the north side of the stream (section 1 , figs 1,2 ). The visible thickness of the sediments in the type section is 38 metres, extending from the present stream bed at 24 metres above sea level to 62 metres above sea level.

The base of the formation is hidden beneath the present stream bed. However, a few hundred metres up stream from section 1, Lower Jurassic shale of the Neil Klinter Formation is exposed (Friderichsen \& Bromley 1974). Jurassic shale occurs up to an altitude only a few metres lower than the lowest recorded part of the Lodin Elv Formation (fig. 1) and probably forms its substrate.

The formation is covered by coarse sand and gravel constituting an extensive fluvial terrace in the area. A C-14 date of shells from the base of the terrace gave an age of 8750 years B. P. (GGU 106511 , corrected for reservoir effect), which is consistent with other dates from the area and 


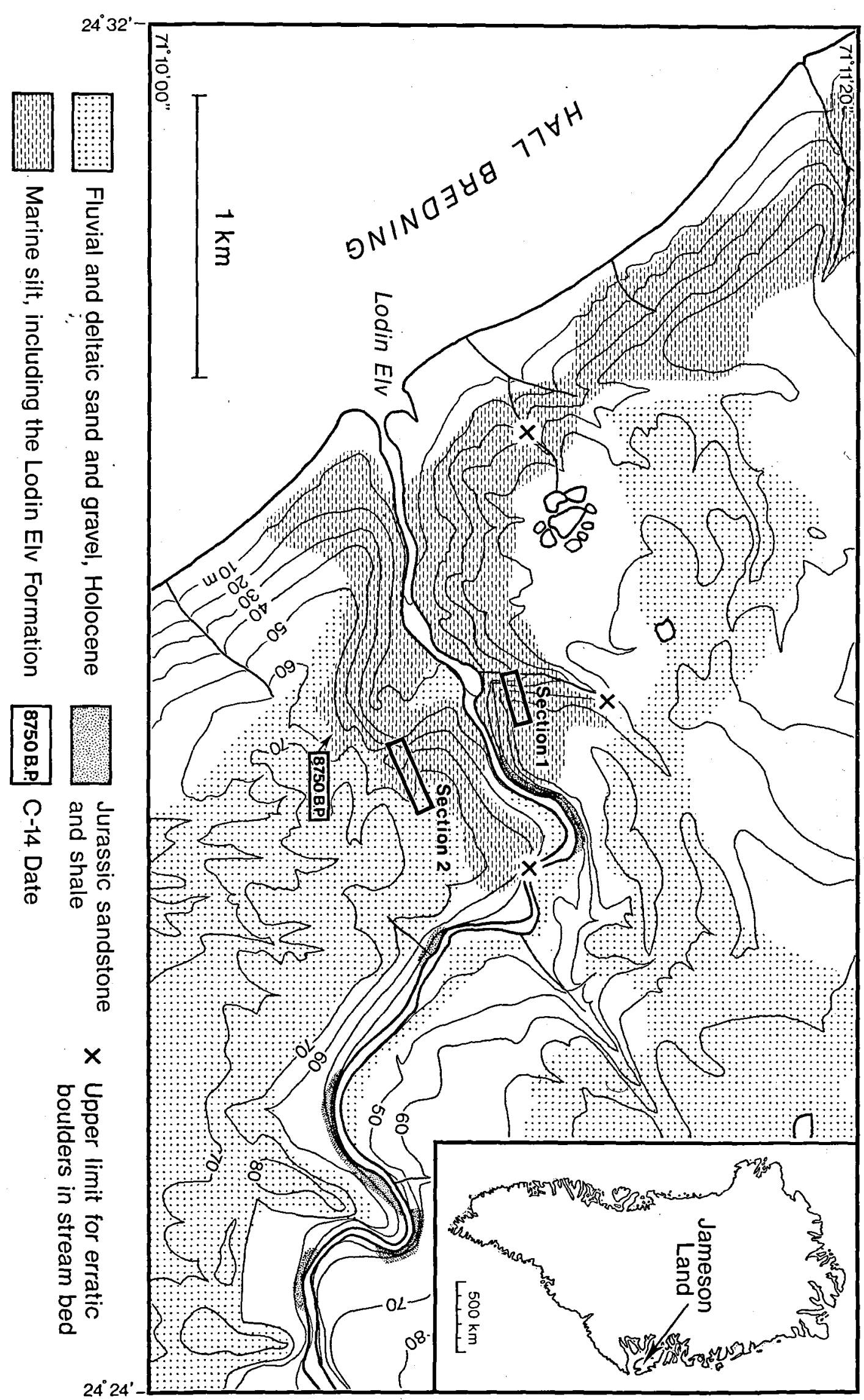

Fig. 1. Geological map of the area at the mouth of Lodin Elv. Inset showing location of Jameson Land. 


\section{Section 1}

\section{Section 2}
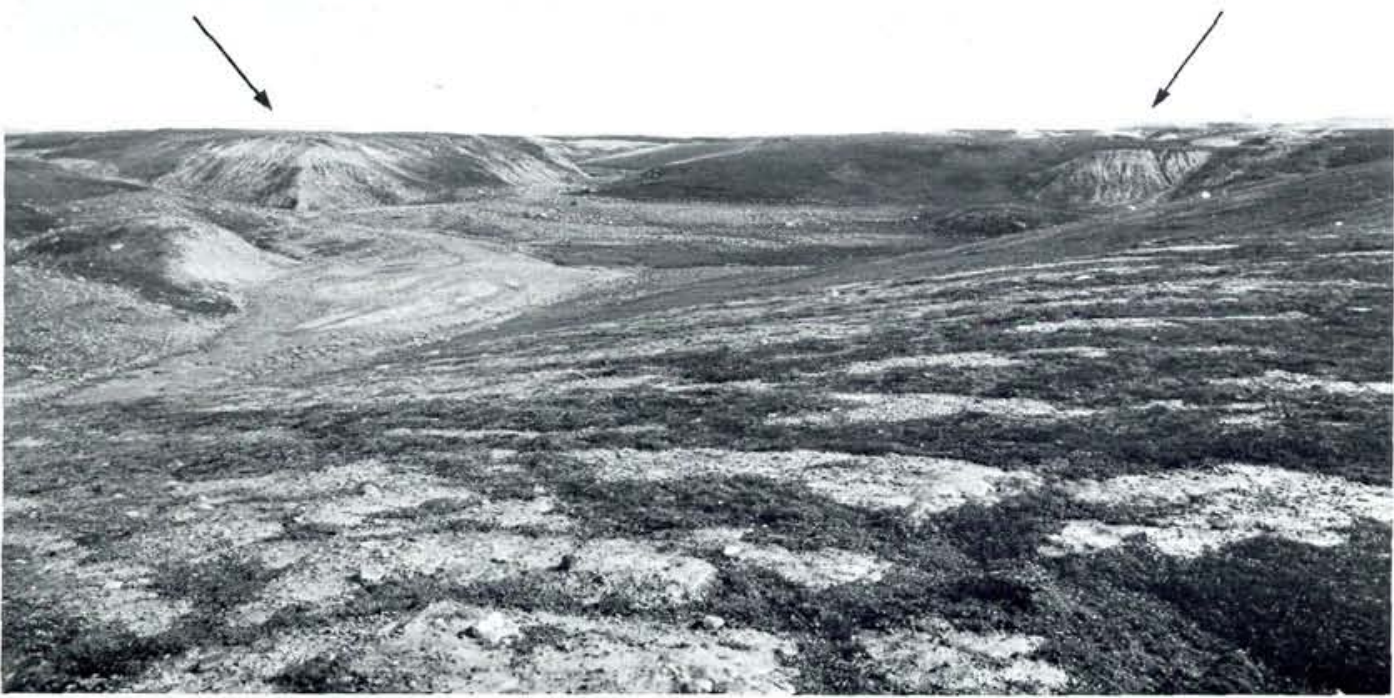

N

\section{Section 1}

S

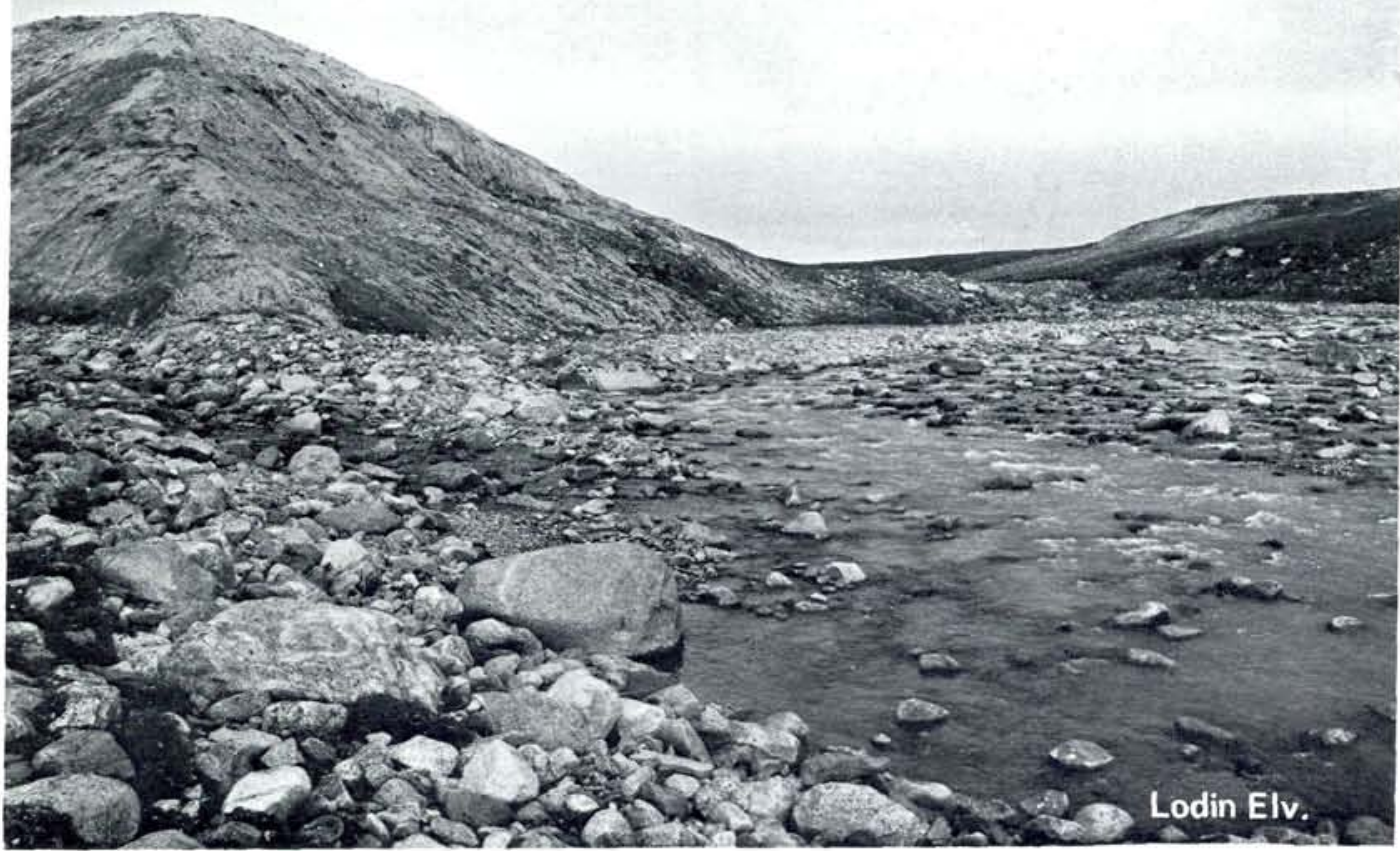

Fig. 2. The sections at Lodin Elv. In the foreground on the upper picture Holocene sand and gravel. Boulders washed out from diamicton cover the stream bed.

shows that the terrace was formed after the collapse of the most recent glacier in the adjacent Hall Bredning, that of the Milne Land Stadial
(Funder 1978). The granulometric composition of a sample from these sediments is shown in figure 4. 


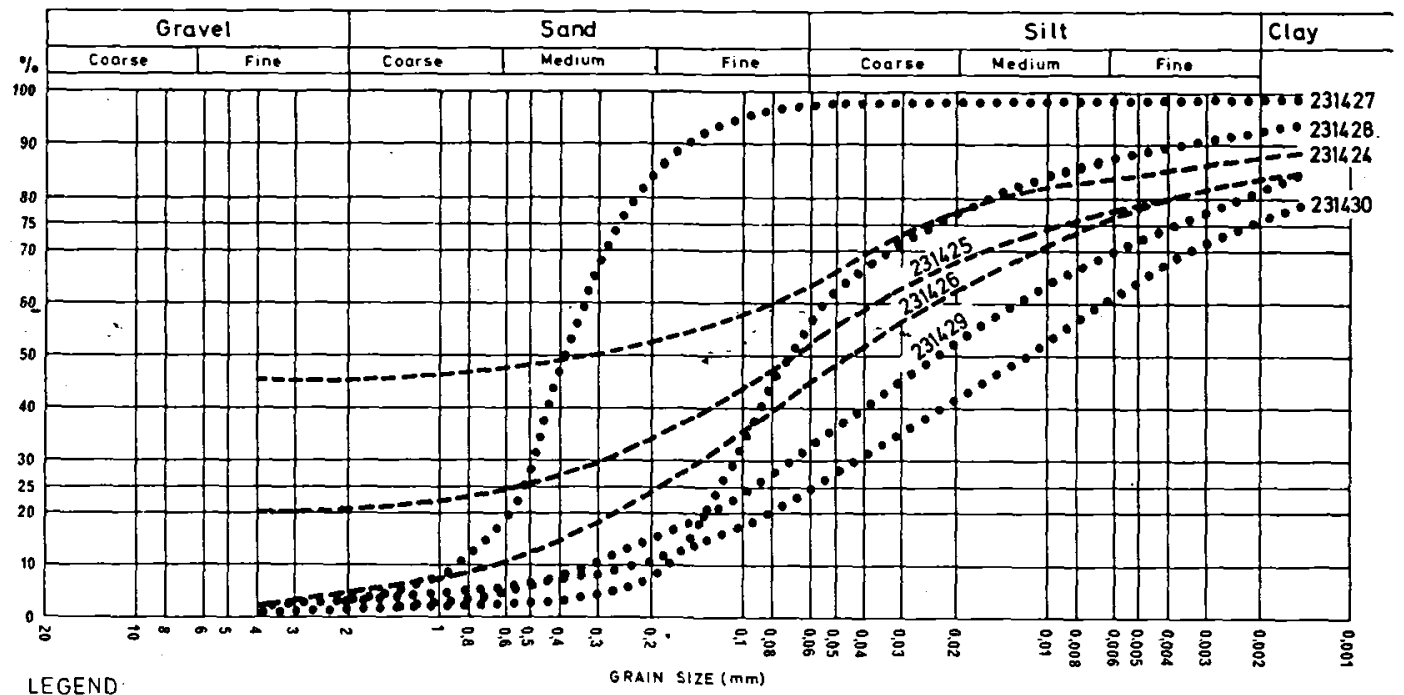

LEGEND

GRAIN SIZE (mm)

\begin{tabular}{|c|ccl|l|l|}
\hline$-\cdots-$ & GGU NO. 231424-231426 & Diamicton, Member B & & \\
\hline$\cdots \cdots$ & GGU NO. 231427-231430 & Silt \& Sand, Member A & & \\
\hline
\end{tabular}

Fig. 3. The granulometric composition of seven samples from section 1, the Lodin Elv Formation.

\section{Lithology}

The sedimentary sequence has been recorded from excavations below the solifluction cover on the stream cliff, and it is informally divided into two members.

Member A, 24 to 42 metres above sea level:
Sand and silt, horizontally layered with layers from 2 to $50 \mathrm{~cm}$ beds of homogeneous sandy silt in the lower part. The granulometric composition of four samples is shown in figure 3 , showing the development from poorly sorted, homogenous sandy silt at the base to well-sorted, layered sand at the top. Stone counts within the grain-size

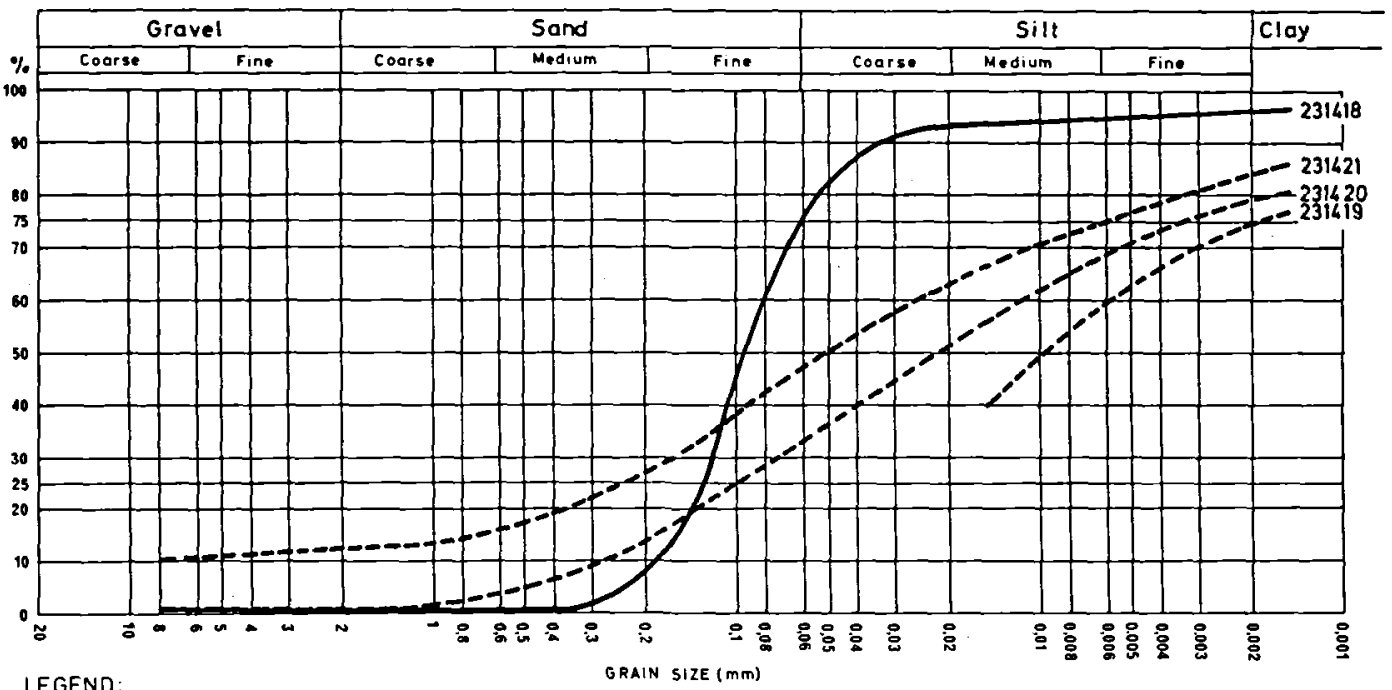

LEGEND

GRAIN SIZE (mm)

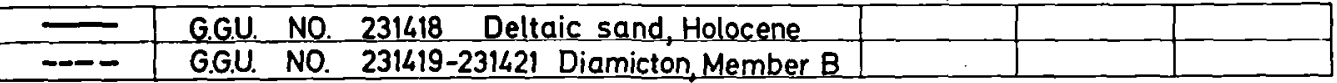

Fig. 4. The granulometric composition of four samples from section 2 of the Lodin Elv Formation and the covering Holocene deltaic sand. 
interval 2-4 $\mathrm{mm}$ and $>4 \mathrm{~mm}$ show that sandstones, possibly of local origin, are represented by $20-10 \%$, while the remainder is crystalline rock types. Crystalline rock types form the bedrock in the western part of the fjord complex.

Pebbles, tiny mollusc shells, shell fragments, and plant detritus occur scattered throughout this member.

Member B, 42 to $62 \mathrm{~m}$, above sea level:

Matrix supported silty to sandy diacmicton with occasional 2 to $5 \mathrm{~cm}$. thick layers of sand. The diamicton contains boulders up to $2 \mathrm{~m}$ in diameter, mainly granite and gneiss, but also some dolerite. Boulders of the local sandstone are extremely rare. Stone counts within the same size intervals as in member A show that sandstone constitutes about $10 \%$ of the total. Examples of glacial striations are found on some of the larger particles. Such striations have earlier been demonstrated in Danish glaciomarine deposits (Bahnson et al. 1974, plate 6 fig. 2).

Mollusc shells and plant remains occur scattered.

The granulometric composition of three matrix samples from the diamicton is shown in figure 3 .

\section{Interpretation}

The sediments of member A are, because of their layering and the general coarsening upwards tendency, interpreted as pro-deltaic, the occurrence of marine fossils suggests a marine environment.

Member B is, on the basis of its fine-grained matrix and its content of well preserved marine mollusc shells forming a "natural" fauna community, interpreted as a marine sublittoral suspension sediment with an admixture of ice rafted debris and boulders.

\section{Distribution}

The diamicton of member $\mathrm{B}$ occurs also on the south side of Lodin Elv in section 2 (figs 1,2) where it has been excavated from 35 metres above sea level to its top 48 metres above sea level (fig. 5). The granulometric composition of three samples from this member in section 2 is shown in figure 4 . Also here stone counts show a

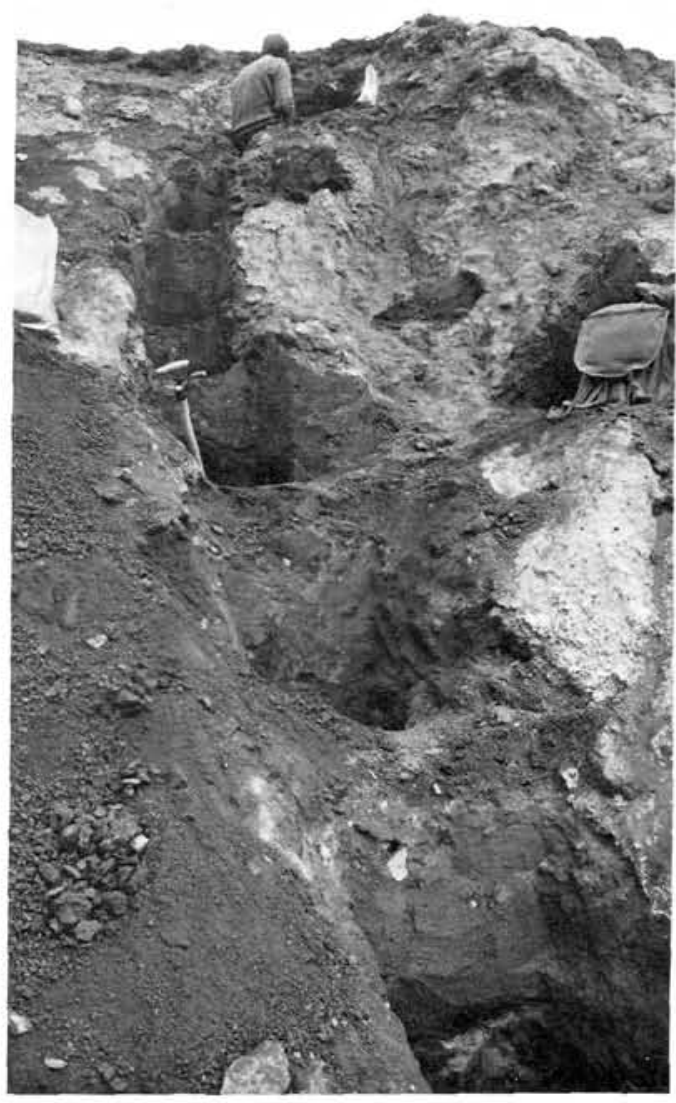

Fig. 5. Excavations in section 2. Extensinve digging is necessary to penetrate the mantle of soliflucted material.

$90 \%$ representation of crystalline rock types with glacial striations on some of the larger particles.

Since the sediments of the Lodin Elv Formation are everywhere covered by a mantle of soliflucted material, their general distribution is not clear.

One characteristic feature of the formation is the large boulders of member B. These occur in great abundance and with a clearly defined upper limit both in the bed of Lodin Elv and in a smaller stream to the north (figs 1,2). The occurrence of these washed-out boulders indicates that the Lodin Elv Formation occupies an area extending one $\mathrm{km}$ along the coast and 500 to $1000 \mathrm{~m}$ inland.

The sediments show no sign of disturbance, and we suggest that the Lodin Elv Formation occurs as an erosional remnant surrounded by the Holocene and Weichselian marine and fluvial sediments of the region (Funder 1978). 


\section{Foraminifera}

\section{Laboratory processing}

Two hundred grams of eleven samples were crushed so that no particle remained larger than 1 $\mathrm{cm}^{3}$. Each sample was subsequently soaked in a $5-10 \%$ solution of hydrogene peroxide $\left(\mathrm{H}_{2} \mathrm{O}_{2}\right)$ for about 15 minutes, and after disintegration washed through a sieve with mesh diameter 0.1 $\mathrm{mm}$. The residue upon the screen was dried and, as most of the samples contained a considerable amount of sand grains, the foraminifera were concentrated by means of dibromethene $\left(\mathrm{C}_{2} \mathrm{H}_{4} \mathrm{Br}_{2}\right)$ diluted with absolute alcohol to specific weight $1.8 \mathrm{~g} / \mathrm{cm}^{3}$ (cf. Feyling-Hanssen 1964, 1976).

\section{Microscopic examination}

The foraminifera of each sample were identified and counted. In samples with few foraminifera, the whole content was counted, in rich samples only a part of it. The result of each analysis is a list of species, the frequency of each species and its percentage of the counted assemblage. To visualize the distribution of species through the sections the analyses were transferred to a range chart (fig. 6), where the percentage distribution of the most significant species is illustrated by symbols. Species observed only in the uncounted part of a sample, were entered in the diagram with an $x$.

\section{Microfossil biostratigraphy}

The foraminiferal composition of the fossil assemblages from Lodin Elv makes a grouping of the samples into three main units possible: Zone III with no foraminifera, zone II with high frequency of Cassidulina cf. teretis, and zone I with firm representation of Cibicides grossa. These units conform with the lithology of the two investigated sections.

Zone III, represented by GGU 231418 from the uppermost horizontally stratified sand-gravel of section 2, is barren of foraminifera. This may be a primary feature, or it may be caused by postdepositional leaching and dissolution of foraminiferal tests. However, the sediment still contains $\mathrm{CaCO}_{3}(1 \%$, fig. 11).

Zone II, comprising the GGU 231419, 231420 and 231421 of section 2 and 231424, 231425 and 231426 of section 1 , is characterized by high frequency of Cassidulina cf. teretis (25 to $52 \%$ ). Frequent are also Epistominella vitrea ( 7 to $31 \%$ ) and Elphidium excavatum (8 to $33 \%$ ). Stainforthia loeblichi occurs in all the samples of the zone, but more frequently in section $2(4$ to $9 \%$ ) than in section 1 (1 to $2 \%)$. Cassidulina reniforme and Nonion orbiculare, on the other hand, are more common in the samples of section 1 than in those of section 2. Six specimens of Islandiella islandica (1\%) occurred in GGU 231420 of section 2 and 21 specimens $(3 \%)$ in 231421 . It was observed also in GGU 231419, but did not occur in the samples of section 1 .

When compared with occurrences in Baffin Island (Feyling-Hanssen 1976, 1980a, b) this trend of occurrences may indicate that the GGU 231419,231420 and 231421 of section 2 represent a younger part of zone II than the 231424 , 231425 and 231426 of section 1.

There is a total of 53 different species in zone II. The number of species per sample ranges from 13 (GGU 231425) to 30 (GGU 231426), the average for zone II being 22 .

\section{PLATE 1}

Fig. 1. Quinqueloculina borea Gudina, from GGU 231419, zone II. $\times 45$. MGUH 16003 . Fig. 2. Guttulina dawsoni Cushman and Ozawa, from GGU 231426, zone II. $\times 75$. MGUH 16004. Fig. 3. Guttulina problema d'Orbigny, from GGU 231426, zone II. $\times 75$. MGUH 16005. Fig. 4. Dentalina ittai Loeblich and Tappan, GGU 231430, zone I. $\times 75$. MGUH 16006. Fig. 5. Dentalina baggi Galloway and Wissler, GGU 231424, zone II. $\times 60$. MGUH 16007. Figs. 6,7,8. Cassidulina cf. teretis Tappan, from GGU 231421, zone II. 6 and 8 , opposite sides; 7, edge view, $\times 75$. MGUH 16008. Fig. 9. Cassidulina teretis Tappan, side view of specimen from GGU 231424, Zone II. $\times 75$. MGUH 16009. Fig. 10. Cassidulina reniforme Nørvang, side view of specimen from GGU 231426, zone II. $\times$ 75. MGUH 16010. Figs. 11, 12, 13. Cassidulina cf.teretis Tappan, GGU 231430, zone I. 11 and 13, opposite sides showing uncovered central part; 12 , edge view showing vawy periphery. $\times 75$. MGUH 16011. Fig. 14. Stainforthia loeblichi (FeylingHanssen), GGU 231430, zone I. $\times 75$. MGUH 16012. Fig. 15. Angulogerina fluens Todd, GGU 231421, zone II. $\times 75$. MGUH 16013. Fig. 16. Stainforthia schreibersiana (Czjzek), from GGU 231421, zone II. $\times 75$. MGUH 16014. Fig. 17, 18, 19. Islandiella islandica Nørvang, from GGU 231420, zone II. 17 and 19, opposite sides; 18, edge view with aperture. X75. MGUH 16015. Fig. 20. Glandulina laevigata d'Orbigny, from GGU 231426, zone II. ×75. MGUH 16016. 


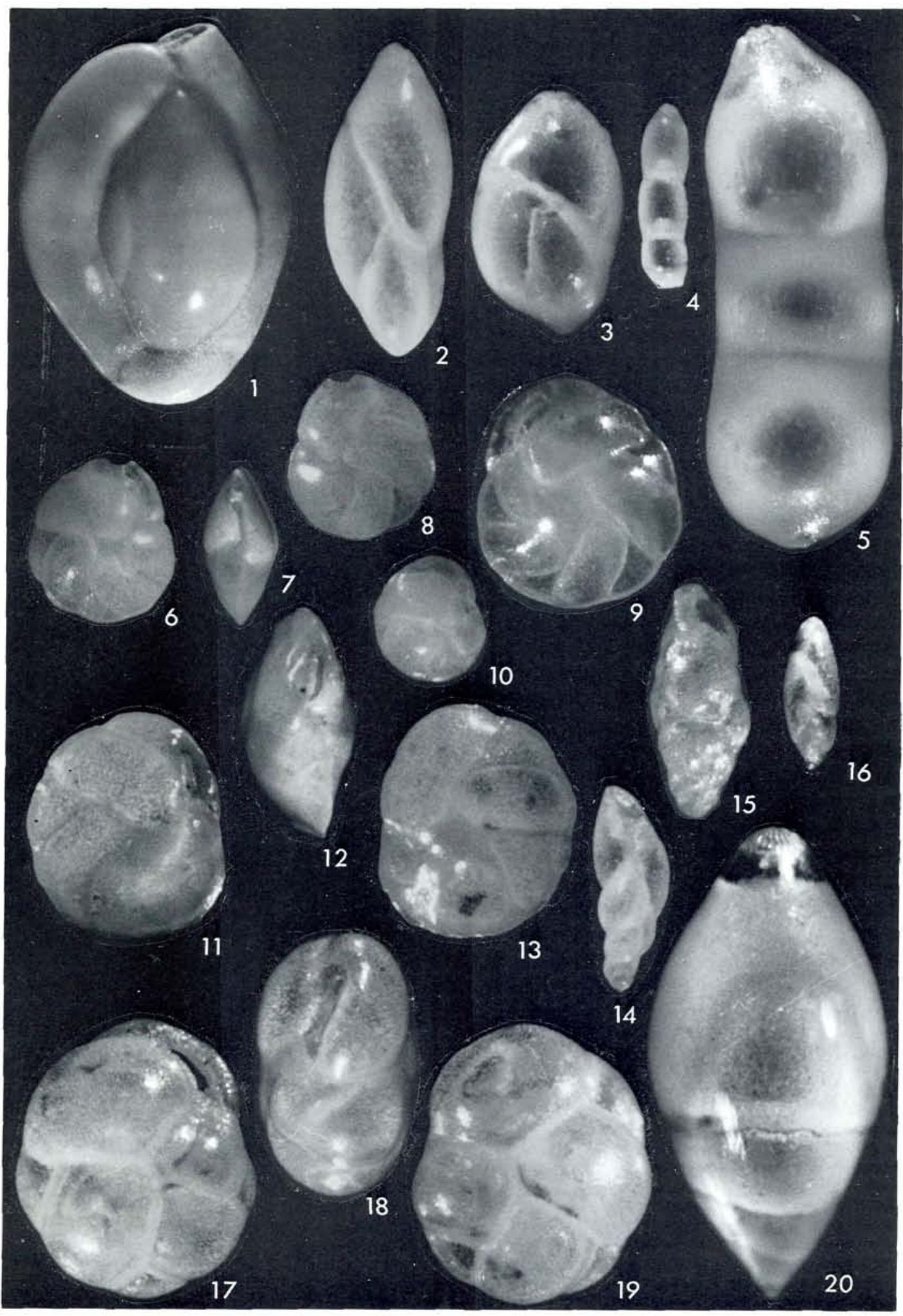




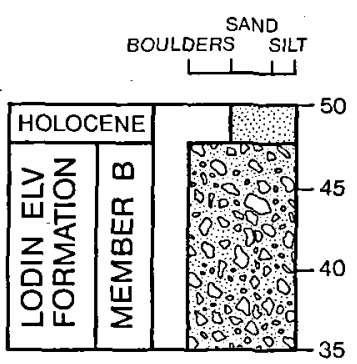

\section{FREQUENCY DISTRIBUTION OF 17 SELECTED TAXA OF FORAMINIFERA}

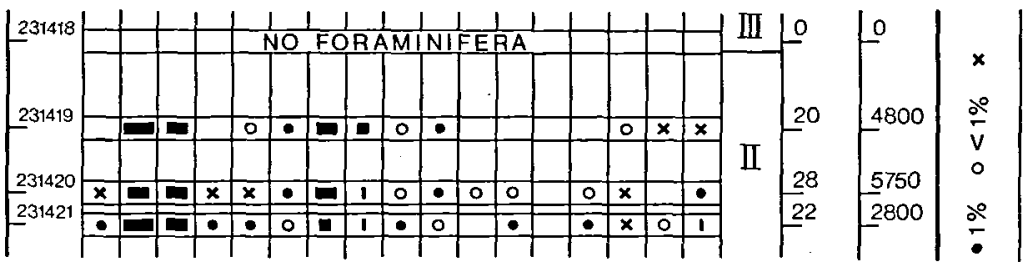

SECTION 2

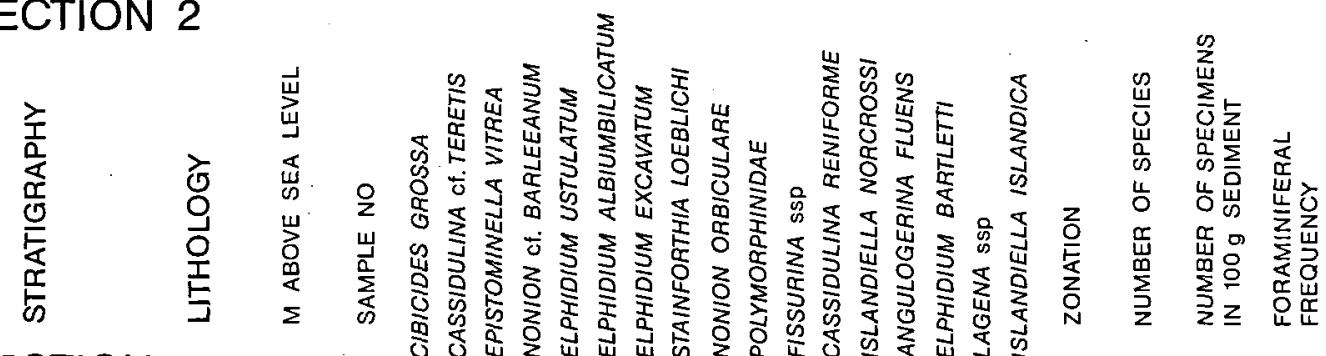

\section{SECTION 1}
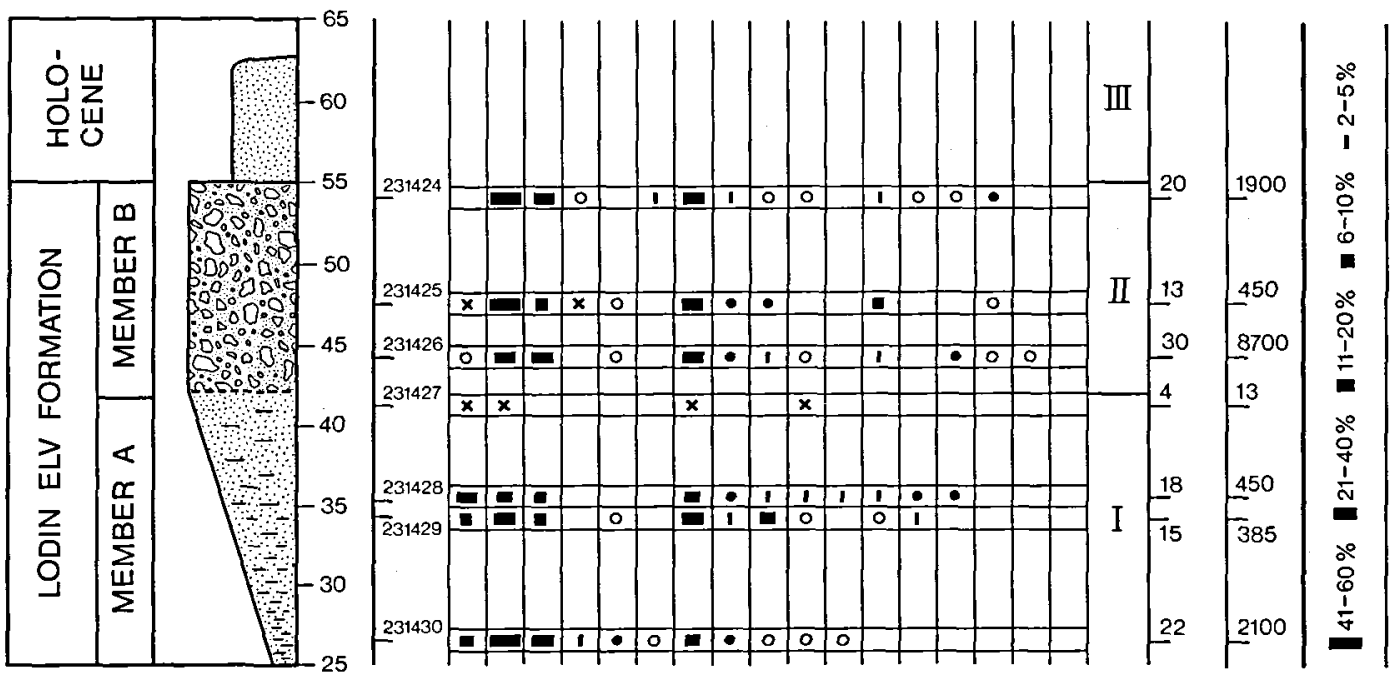

Fig. 6. Foraminiferal range chart for sections 1 and 2. Species observed only in the uncounted part of a sample marked by an X.

A reworked specimen of Cibicides grossa was observed in the uncounted part of GGU 231420 and also one in 231425 and 231426 . Five speci- mens of this species $(1 \%)$ occurred in GGU 231421. They seem to be well preserved and may belong to the original assemblage of that sample.

\section{PLATE 2}

Figs. 1-3. Cibicides lobatulus (Walker and Jacob), from GGU 231430, zone I. 1, spiral side; 2 , edge view; 3, umbilical side. $\times 75$. MGUH 16017. Figs. 4-6. Buccella frigida (Cushman), from GGU 231430, zone I. 4, spiral view; 5, edge view; 6, umbilical view. $\times 75$. MGUH 16018. Figs. 7, 8. Epistominella vitrea Parker, from GGU 231430 , zone I. 7, spiral side; 8 , umbilical side. $\times 75$. MGUH 16019. Figs. 9-11. Cibicides grossa Ten Dam and Reinhold, from GGU 231430, zone I. 9, strongly convex umbilical side; 10, edge view, the aperture is a continuous slit, foreign particles and a hole above the lip give it a divided appearance in the present specimen; 11, slightly conves spiral side. $\times 60$. MGUH 16020. Figs. 12, 13. Nonion cf. barleeanum (Williamson), from GGU 231430, sample no. 231430 , zone I. 12, side view; 13, edge view with aperture. $\times 75$. MGUH 16021. Figs. 14-16. Cibicides grossa Ten Dam and Reinhold, from GGU 231430 , zone I. 14 , strongly convex unbilical side; 15 , edge view; 16 , slightly convex spiral side. $\times 75$. MGUH 16022. 


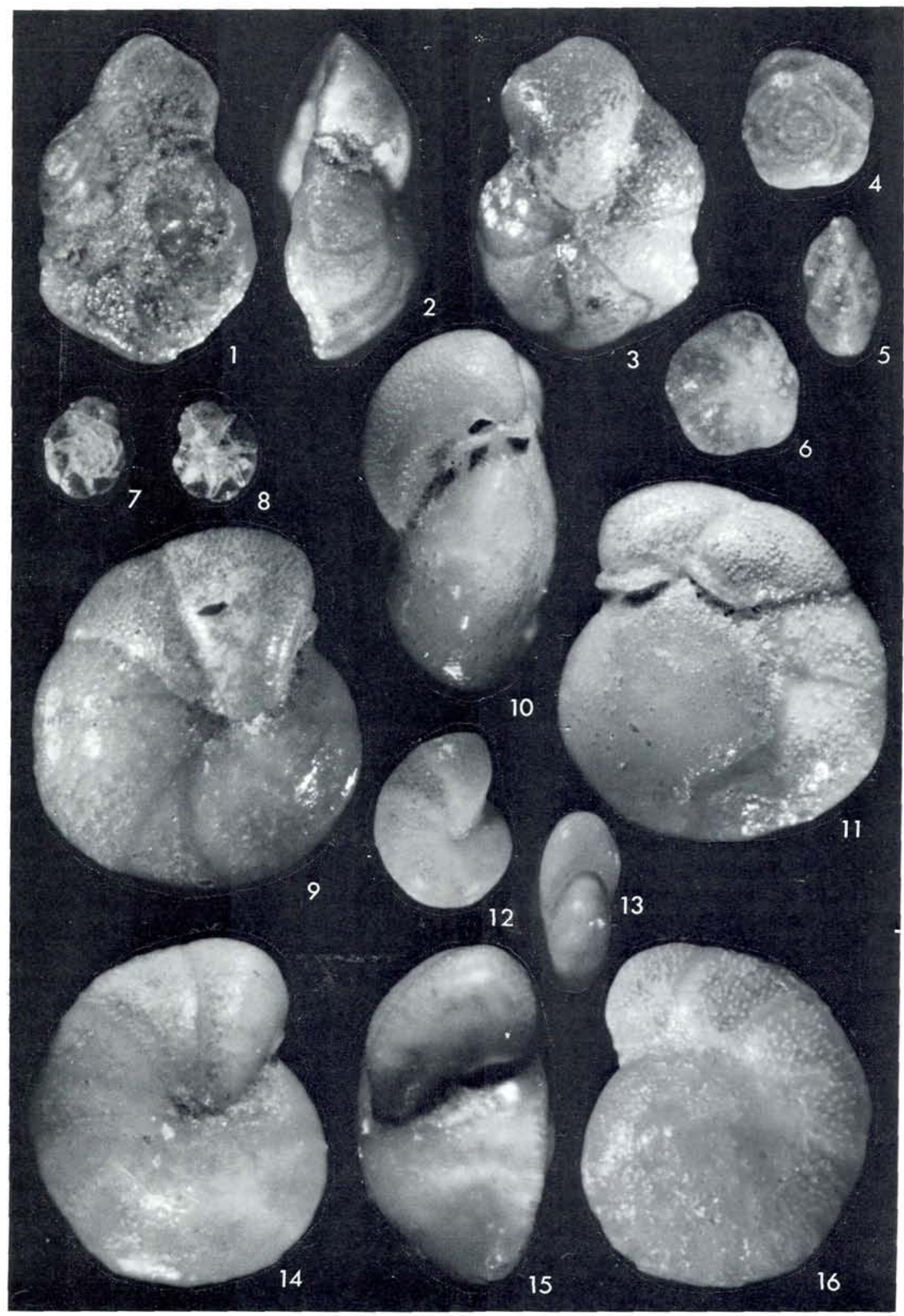


Zone I, comprises the four lowest samples of section 1, viz.: GGU 231427, 28, 29 and 30. The total number of different foraminiferal species in zone $\mathrm{I}$ is 35 , and the highest number of species in one sample was 22 (GGU 231430). All these numbers are thus lower than for zone II.

The characteristic feature of zone $I$ is its high frequency of the species Cibicides grossa, $36 \%$ in GGU 231428 , $9 \%$ in 231429 , and $15 \%$ in 231430. Even in the almost barren 231427 were three specimens of Cibicides grossa. This large and prominent species is absent or occurs only occasionally in zone II.

Cassidulina cf. teretis is frequent also in zone $I$ (20 to $44 \%$ ), and so are Epistominelle vitrea ( 8 to $21 \%$ ) and Elphidium excavatum (11 to $25 \%$ ). Nonion orbiculare is frequent $(12 \%)$ in GGU 231429 , and Nonion cf. barleeanum makes $2 \%$ of the assemblage of 231430 .

Among the species that occur in zone II but not in zone I are Nonion labradoricum and Astrononion gallowayi (not on the diagram) and $I s-$ landiella islandica.

\section{Paleoenvironment}

The foraminiferal assemblages of the Lodin Elv Formation reflect inner shelf environments of sligthly varying depth. Cassidulina laevigata, which comes close to Cassidulina cf. teretis of the present samples, does occur in deep water (e.g. Sejrup et al. 1981) but not together with so many Elphidium as in the present assemblages. In addition to the Elphidium species on the diagram of fig. 6, E. asklundi, E. incertum, E. groenlandicum and $E$. subarcticum occurred. The absence of planktonic foraminifera is also in concert with an inner shelf environment - and so is, most probably, also the present-day position of the Lodin
Elv deposits: $25-55 \mathrm{~m}$ above the actual sea level. Cassidulina teretis (recorded as C. laevigata or C. carinata) is frequent in Lower Quaternary-Upper Tertiary shallow-water deposits in the Netherlands and Belgium (e.g. Dam \& Reinhold 1941; van Voorthuysen 1950; cf. Feyling-Hanssen 1980a, b).

Generally, zone I seems to reflect somewhat shallower water than zone II. A minimum may have occurred at the level of GGU 231429 with the many Nonion orbiculare.

As to temperature, the foraminiferal assemblages of the Lodin Elv Formation do not reflect high arctic water conditions. Many of the species both in zone II and zone I occur in arctic as well as in boreal waters of the present day. But some of them are mainly of boreal, i.e. of a more southern habitat. If thus Cassidulina cf. teretis, Nonion cf. barleeanum and Elphidium albiumbilicatum are considered mainly boreal in distribution, and also Cibicides grossa and Elphidium ustulatum, which have not been recorded from Recent waters, are regarded as warmer-water indicators (Feyling-Hanssen 1980a b, 1981), the content of boreal specimens per sample amounts to an average of $44 \%$ in zone II and $52 \%$ in zone I. This would indicate a remarkably strong amelioration of the marine-climatic conditions compared to the present-day high arctic conditions at the site of Lodin Elv.

Cassidulina teretis, as described by Tappan (1951) from the Gubik Formation of Point Barrow and as present in the Clyde Foreland Formation and at Qivituq Peninsula of Baffin Island, abounds in Upper Tertiary depostis of the Netherlands and Belgium. Cassidulina cf. teretis of the present material comprises Cassidulina teretis Tappan but also forms which are related to Cassidulina laevigata d'Orbigny and even transitional forms. Such Cassidulina cf. teretis seem

PLATE 3

Figs. 1, 2. Nonion labradoricum (Dawson), from GGU 231426, zone II. 1, side view; 2, apertural view. $\times 75$. MGUH 16023. Figs. 3, 4. Nonion orbiculare (Brady), from GGU 231429, zone I. 3, side view; 4, edge view. X75. MGUH 16024. Figs. 5-8. Nonion cf. barleeanum (Williamson). 5 and 8 , side view of two specimens from sample no. 231421, zone II; 6 and 7 , side and edge view of a specimen from GGU 231430, zone I. All $\times 75$. MGUH 16025. Figs. 9, 10. Elphidium albiumbilicatum (Weiss), side and edge view of a specimen from GGU 231424 , zone II. $\times 75$. MGUH 16026. Figs. 11, 12. Elphidium ustulatum Todd, edge and side view of a specimen from GGU 231420 , zone II. $\times 75$. MGUH 16027. Figs. 13, 14. Elphidium asklundi Brotzen, side and edge view of a specimen from GGU 231426, zone II. $\times 75$. MGUH 16028. Figs. 15,16 . Elphidium excavatum (Terquem), forma alba Feyling-Hanssen, side and edge view of a specimen from GGU 231426, zone II. $\times 75$. MGUH 16029. Figs. 17, 18. Elphidium excavatum (Terquem), forma clavata Cushman, side and edge view of a specimen from GGU 231430, zone I. $\times 75$. MGUH 16030. Fig. 19. Elphidium bartletti Cushman, side view of a specimen from GGU 231426, zone II. ×75 MGUH 16031. 







\begin{tabular}{|c|c|c|c|}
\hline $\mathrm{EPOCH}$ & LODIN ELV & CLYDE FORELAND & QIVITUQ PENINSULA \\
\hline \multirow{2}{*}{ HOLOCENE } & \multirow{2}{*}{ ZONE III } & \multirow{6}{*}{$\begin{array}{l}\text { ISLANDIELLA } \\
\text { ISLANDICA } \\
\text { ZONE }\end{array}$} & ZONE A \\
\hline & & & ZONE B \\
\hline \multirow{5}{*}{ PLEISTOCENE } & & & ZONE C \\
\hline & & & ZONE D \\
\hline & & & ZONE E \\
\hline & & & ZONE F \\
\hline & ZONE II & $\begin{array}{c}\text { CASSIDULINA } \\
\text { TERETIS } \\
\text { ZONE }\end{array}$ & ZONE G \\
\hline PLIOCENE & ZONE I & $\begin{array}{c}\text { CIBICIDES } \\
\text { GROSSA } \\
\text { ZONE }\end{array}$ & ZONE H \\
\hline
\end{tabular}

Fig. 7. Correlation of foraminiferal units in Baffin Island and East Greenland.

still to live in arctic seas, but at depths influenced by Atlantic water (Vilks 1964, 1969; Wilks et al. 1979; Lorange 1977; Feyling-Hanssen 1980a). Cassidulina laevigata abounds in present-day boreal shelf waters, as for instance the North Sea (Jarke 1961; Feyling-Hanssen 1981).

Most of the Elphidium excavatum are of forma clavata Cushman which seems to prefer arctic environments, but many of them are represented by forma selseyensis Heron-Allen and Earland and some by forma alba Feyling-Hanssen - both of which prefer boreal waters (Feyling-Hanssen 1972).

\section{Correlation and age}

The foraminiferal assemblages of the Lodin Elv Formation show great affinity to assemblages from the Clyde Foreland Formation and from the Qivituq Peninsula of Baffin Island, arctic Canada (Feyling-Hanssen 1976, 1980a, b). Zone I and II seem to correlate with the Cibicides grossa zone and the Cassidulina teretis zone of the Clyde Foreland Formation - respectively - and with zone $\mathrm{H}$ and zone $\mathrm{G}$ of the Qivituq Peninsula (fig. 7).

A Nonion tallahattensis zone or a zone $\mathrm{J}$, which occurs below the Cibicides grossa-bearing units in Baffin Island (Feyling-Hanssen 1976, 1980a), is not represented in the samples from Lodin Elv.
In particular the assemblages of zone I with their large Cibicides grossa seem almost identical with assemblages from the lower part of the Cibicides grossa zone of the Clyde Foreland Formation (cf. Profile VII of Clyde Foreland, Feyling-Hanssen 1976: 337; reproduced in fig. 8 of the present paper). Large Cibicides grossa are frequent and at the same time Cassidulina teretis is abundant. In other assemblages from Clyde Foreland Cassidulina teretis may be less frequent or lacking in the Cibicides grossa zone (a compilation of some of the Baffin Island profiles is reproduced in fig. 9 of the present paper).

Zone I also correlates with zone $H$ of the Qivituq Peninsula succession (Feyling-Hanssen 1980a:158). Zone H carries large Cibides grossa, but Epistominella vitrea is less frequent than in zone I, and Cassidulina teretis is absent in most zone $\mathrm{H}$ samples.

The Cibides grossa zone and zone $\mathrm{H}$ were on micropaleontological grounds placed in the Upper Tertiary - more precisely in the Pliocene (Feyling-Hanssen 1980a, b). The resemblance between their assemblages and such of Pliocene deposits from deep borings in the central North Sea is striking (Plates 4,5).

By comparison, therefore, zone I of the Lodin Elv Formation is considered to be of Pliocene age.

Zone II has much in common with the Cas- 


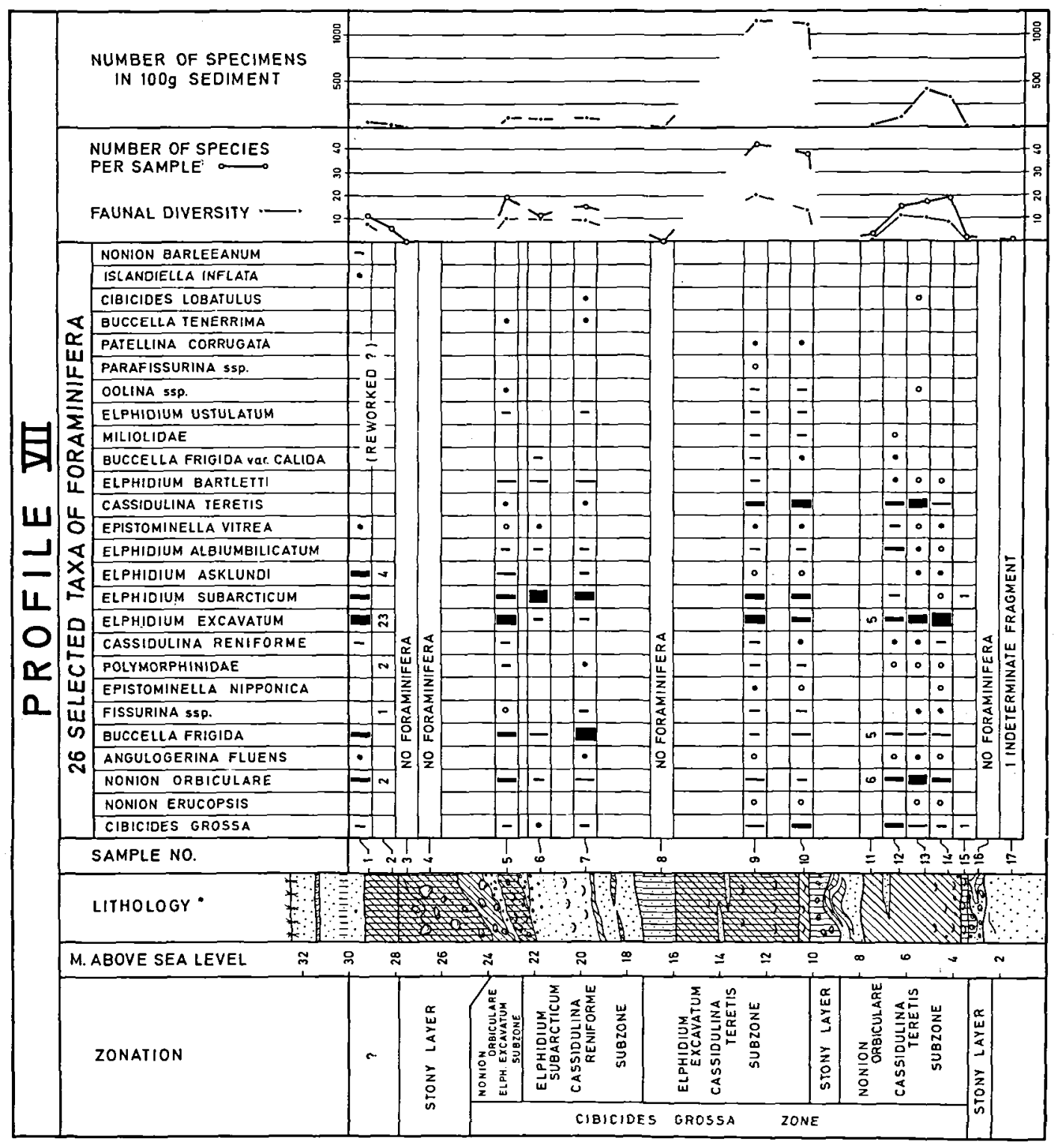

Fig. 8. Profile VII of the Clyde Foreland Formation, Baffin Island. (From Feyling-Hanssen 1976).

sidulina teretis zone of the Clyde Foreland Formation and with zone $\mathrm{G}$ of the Qivituq Peninsula. Cassidulina teretis is common to abundant in their assemblages, and in the field these zones occur next above the Cibicides grossa-bearing units.

The Cassidulina cf. teretis of zone II is not so clearly referable to Cassidulina teretis Tappen as the Baffin Island specimens. Most of them are distinct $C$. teretis, but many of them show in edge view a wavy periphery which is characteristic of C. laevigata d'Orbigny. In contrast to C. laevigata, however, the central ara on each side remains uncovered by the umbilical part of the chamber walls in nearly all specimens from Lodin Elv. Both forms have in the present paper been grouped together in the taxon Cassidulina cf. teretis. Such deviating forms occur also together with characteristic Cassidulina teretis in as- 
semblages above Cibicides grossa assemblages in deep borings from the central North Sea.

In addition to Cassidulina cf. teretis also Epistominella vitrea and Elphidium excavatum are frequent in zone II. Also this is characteristic of many samples from the Cassidulina teretis zone of the Clyde Foreland Formation and of zone $G$ of the Qivituq Peninsula. Nonion orbiculare is less frequent in zone II than in the underlying zone I which is also the case with the corresponding Baffin Island zones. On the other hand, Islandiella inflata and Astrononion gallowayi are rare in zone II whereas they may be quite frequent in the Cassidulina teretis zone and in zone $\mathrm{G}$ of Baffin Island. Islandiella islandica reaches down into zone II from overlying deposits - as it does in the corresponding zones in Baffin Island.

The Cassidulina teretis zone of Clyde Foreland and zone $G$ of the Qivituq Peninsula were considered to represent a transition unit between the Tertiary and the Quaternary (Feyling-Hanssen $1980 \mathrm{a} \& \mathrm{~b}$ ). The present foraminiferal zone II of the Lodin Elv Formation is also referred to this unit.

A boring in the central North Sea revealed assemblages of fossil foraminifera with frequent large Cibicides grossa (Pl.5, fig.3) together with i.a., Cassidulina teretis, Cassidulina reniforme and Elphidium excavatum at about $900 \mathrm{~m}$ below sea floor. At about $700 \mathrm{~m}$ Cassidulina teretis and $C$. cf. teretis dominated the assemblages (Pl.5, fig. 2). Cassidulina reniforme and Elphidium excavatum, among others, and a few Islandiella helenae appeared. In the above-lying unit of the boring Islandiella helenae became dominant.

In a boring in the Fladen Ground area father north in the North Sea a similar succession occurred: A lower part, about $200 \mathrm{~m}$ below sea floor, had large Cibicides grossa and frequent Cassidulina teretis. Higher up in the borehole Cassidulina teretis/C. cf. teretis predominated, and above this unit, at about $170 \mathrm{~m}$, Islandiella helenae was frequent, together with Islandiella islandica in this borehole. Elphidium excavatum and Nonion orbiculare occurred frequently throughout the considered part of the borehole whereas Cassidulina reniforme was rare. Similar sequences have been observed also in other North Sea borings.

King (1980) has published a range chart "Provisional microfaunal zonation - North Sea Cainozoic" in which Cibicides lobatulus grossa (= Cibicides grossa) characterizes his zone TB 17. This zone represents the Late Pliocene and the uppermost part of the Early Pliocene (King, 1980; King et al., 1981). The above-lying zone TB 18 has as its index species Elphidiella hannai (Cushman and Grant, 1927), and its lower part is characterized also by the occurrence of Elphidiella oregonensis (Cushman and Grant, 1927). This lower part of the zone is distinguished as TB $18 \mathrm{a}$. The boundary between the Pliocene and the Pleistocene is placed in the $\mathrm{El}$ phidiella oregonensis subzone of zone TB 18 (cf. also van Voorthuysen et al., 1972).

Doppert (written communication, 1980) correlates his subzone FA2, the Buccella-Cassidulina subzone of the biozonation of the Dutch Neogene, with King's zone TB 17 of the North Sea, i.e., the Cibicides lobatulus grossa zone, and, in accordance with King, considers it Upper Pliocene in age. It equals the Reuverian and the Oosterhout Formation and was by Doppert et al. (1979) correlated with the Belgian biozone BF N6, the Elphidiella hannai-Cribrononion excavatum zone of De Meuter and Laga (1977), equaling the Oorderen Sands, the Kruisschans Sands and the Merksem Sands. At the transition between the Dutch subzone $F_{2}$ and the overlying subzone $\mathrm{FA}_{1}$, the Ammonia-Quinqueloculina subzone, a zonule $\mathrm{F}_{\mathrm{I}}$ with Elphidiella oregonensis is distinguished, and the boundary between the Upper Pliocene and the Lower Pleistocene is placed within this zonule (Doppert, 1980).

The shallow-water species Elphidiella oregonensis was not observed in either the Baffin Island sequences, or at Lodin Elv. A boundary comparison by this marker is therefore not possible. But the present author feels that Pleistocene conditions were not established either in the North Sea or in Baffin Island and Greenland waters until the arctic species Islandiella helenae had replaced Cassidulina teretis/C. cf. teretis in the foramini-

\section{PLATE 4}

Fig. 1. The foraminiferal assemblage from GGU 231430, zone I, Lodin Elv Formation Many Cibicides grossa. Fig. 2. The foraminiferal assemblage of sample no. 13, Profile VII, Cibicides grossa zone, Clyde Foreland Formation. Many Cibicides grossa. 


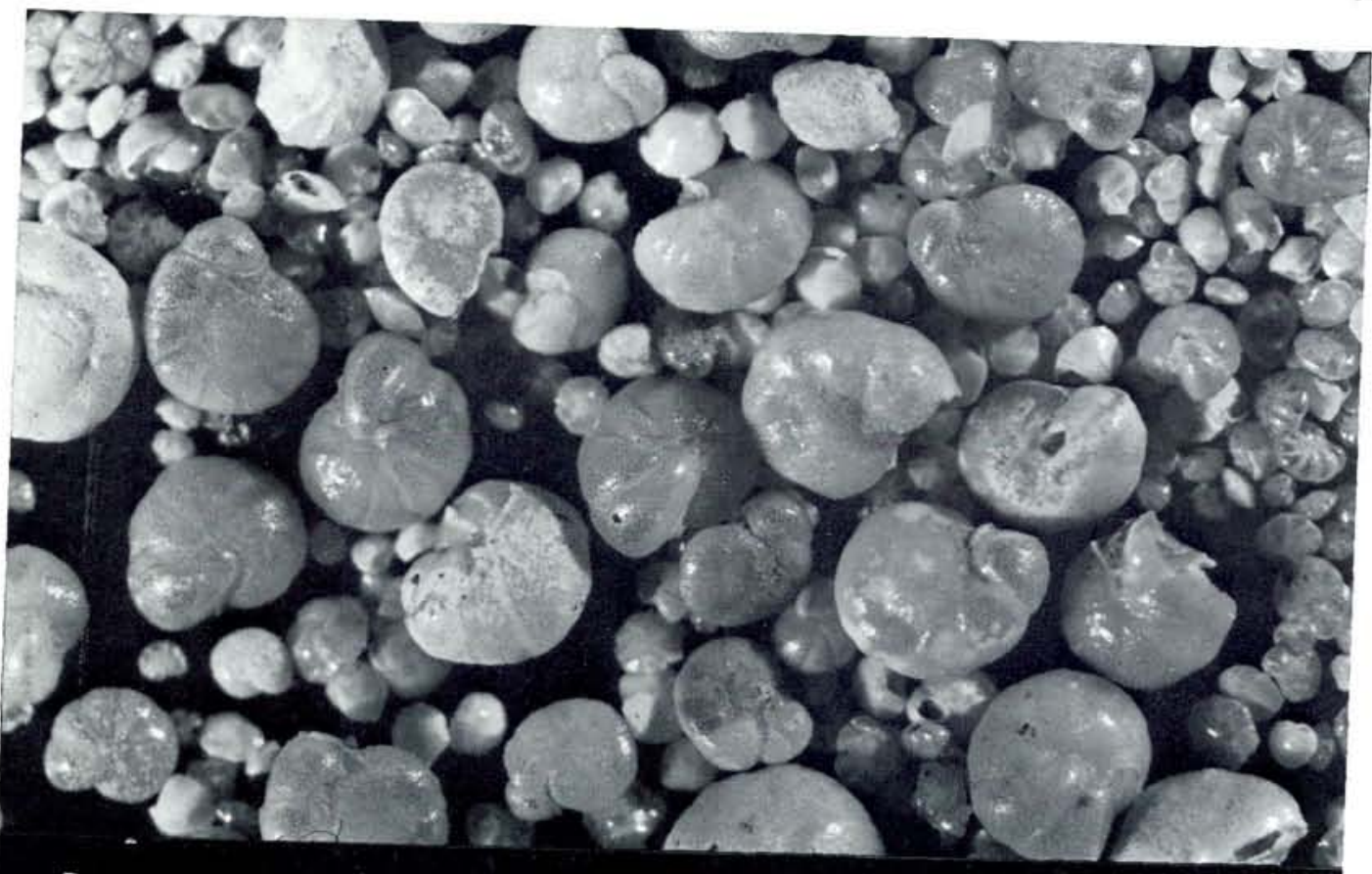

Fig. 1

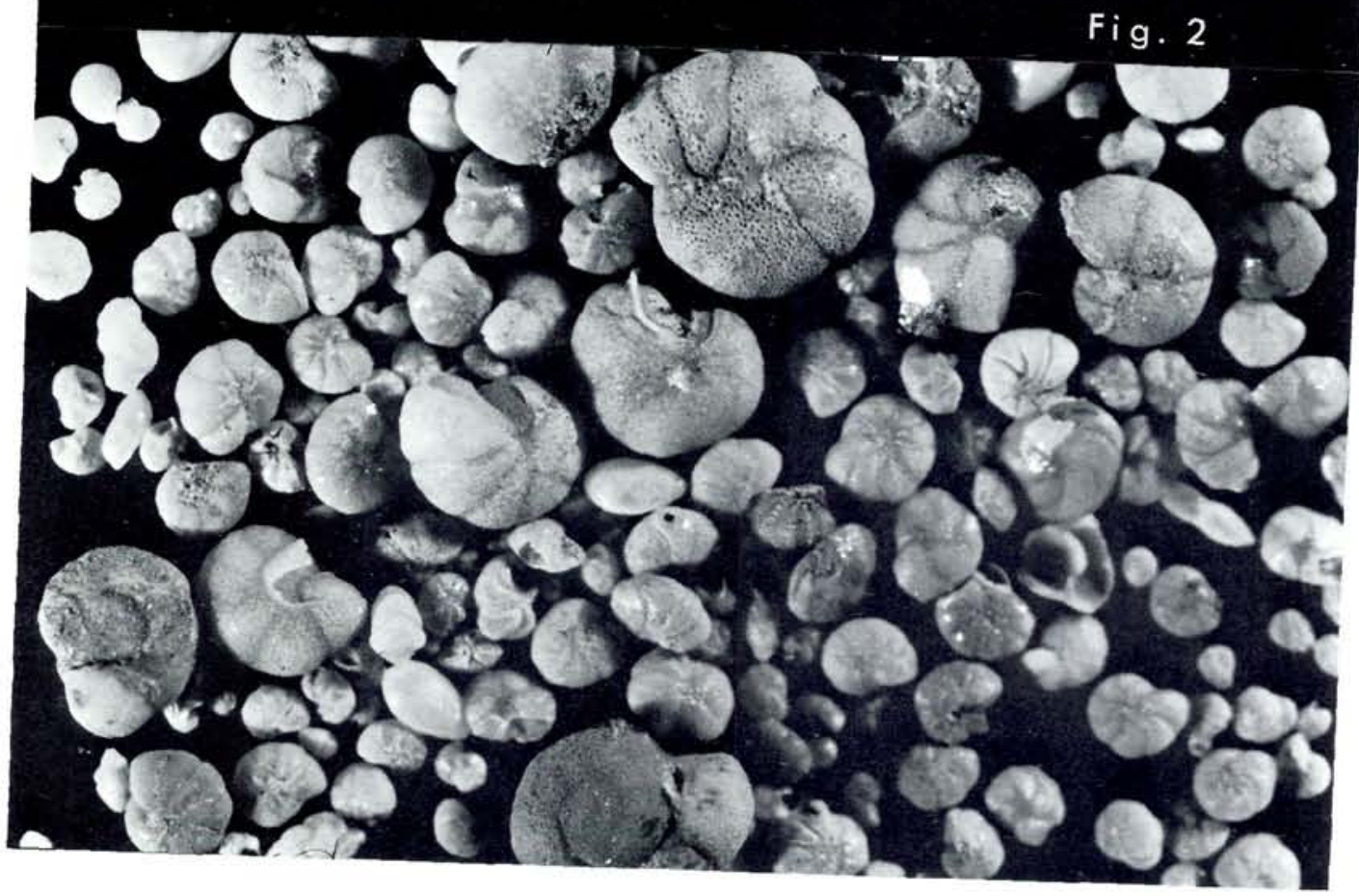




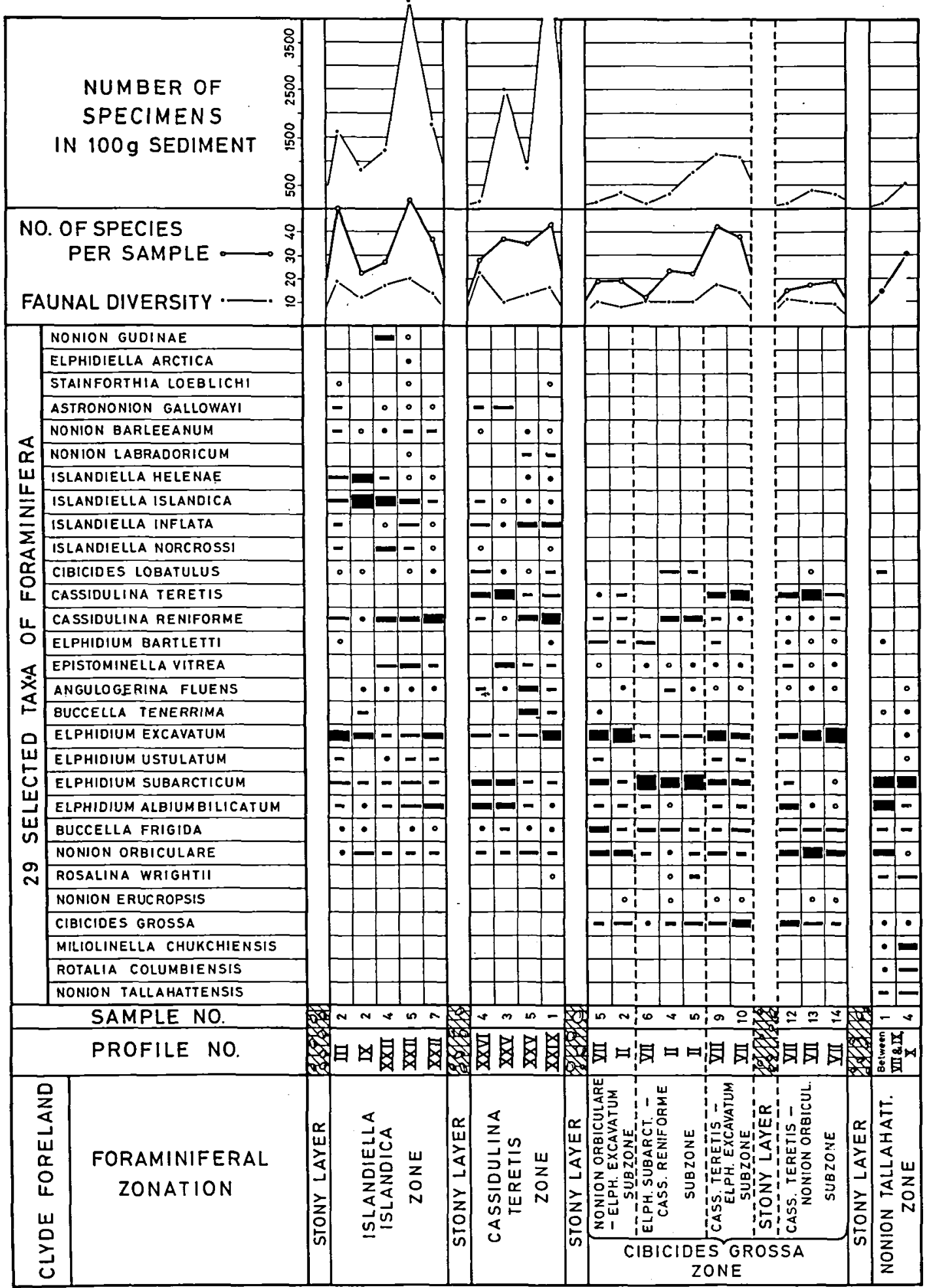

Fig. 9. Foraminiferal zonation of the Clyde Foreland Formation, Baffin Island. (From Feyling-Hanssen 1976.) 


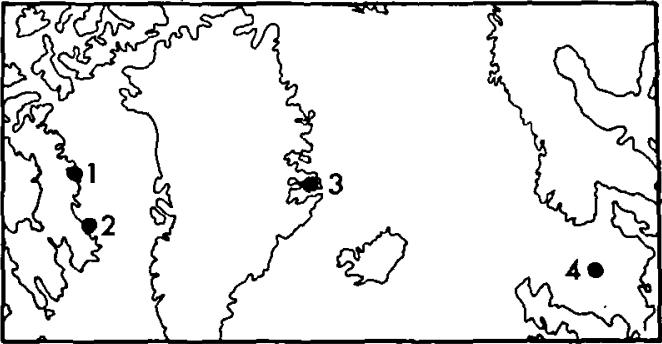

Fig. 10. Localities correlated. 1: Clyde Foreland, Baffin Island. 2: Qivituq Peninsula, Baffin Island. 3. Lodin Elv, East Greenland. 4: Central North Sea.

feral assemblages or had at least entered the assemblages. This happens in the upper part of the Cassidulina teretis zone of the Clyde Foreland, the upper part of zone $G$ at Qivituq Peninsula and in the upper part of the unit with frequent Cassidulina teretis/C. cf. teretis in the North Sea borings.

It does not happen in zone II of the Lodin Elv Formation, which may infer, that the part of the Cassidulina teretis zone which is represented in zone II belongs to the Pliocene rather than to the Pleistocene.

Further investigation is needed to solve the boundary problem in shelf deposits. A subdivision of the Cassidulina teretis zone seems necessary in order to, thereafter, determine which part, or parts, of it belong to the Pliocene and which to the Pleistocene.

But there should be little doubt about a Pliocene age of zone I of the Lodin Elv Formation (= the Cibicides grossa zone of Clyde Foreland). It correlates with Cibicides grossa units of North Sea successions which the present author had the opportunity to examine, and it correlates with the Upper Pliocene Cibicides lobatulus grossa zone (TB 17) established by King (1980; King et al., 1981). If these faunal changes should turn out to be metachronous rather than synchronous, on a larger scale, this would render the Cibicides grossa zone of Clyde Foreland and zone II of Lodin Elv even older rather than younger than their North Sea correlatives because severe conditions capable of exiling the Tertiary Cibicides grossa would probably occur earlier at Clyde Foreland and at Lodin Elv than in the North Sea.
Mollusc faunas

Eleven bulk samples from sections 1 and 2 have been analysed for their content of mollusc shells. Each sample had a weight of $0.5-1 \mathrm{~kg}$, except GGU 231420 and 231426 which weighed $5 \mathrm{~kg}$ each. The samples were.washed through a sieve with a mesh diameter of $0.5 \mathrm{~mm}$. The results of the analyses appear from fig. 11 .

The shells are small and some are fragmented, however, most appear to have fragmented in situ, and only a few show any traces of wear (plates 6,7).

The faunas are poor in species and do not allow any zonation of the deposits. All the identified species and genera, except Lyonsia sp., presently live together at a depth of 25 to 50 metres off the coast of Jameson Land (Thorson 1934, table 2) within the Macoma calcaria community and its transition to the deep water Arca-Astarte crenata community (Thorson 1934). Therefore both the faunal composition and the fresh appearance of the shells indicate that they occur in situ.

Most of the species are widespread and occur over a wide climatic range, from high arctic to bereal. Only Portlandia frigida seems to be restricted to the high arctic sector of the North Atlantic, although the taxonomy of this species is not quite clear (Ockelmann 1958). However, the climatic significance of the fauna lies in the absence of thermophilous species which dominate the mollusc communities in the areas to the south of Scoresby Sund at present.

Astarte crenata occurs rather frequently in some samples, some shells with their periostracum still preserved. This species is extremely rare in the Holocene raised marine deposits (Funder 1978), but occurs rahter frequently in samples from the Weichselian Ice Age in East Greenland (Funder \& Hjort 1973). The cause for this discrepancy is not known, and its presence in the sparse material from Lodin Elv is interesting.

The mollusc fauna is thus of arctic provenance, reflecting and environment that was no less harsh than the present. Similar modern arctic mollusc faunas, composed of species which are widespread within arctic waters today, are known from the Furuvik and Hörgi Formations at Tjörnes, northern Iceland, with an age slightly younger than 2 Ma (Eiríksson 1981). From the 


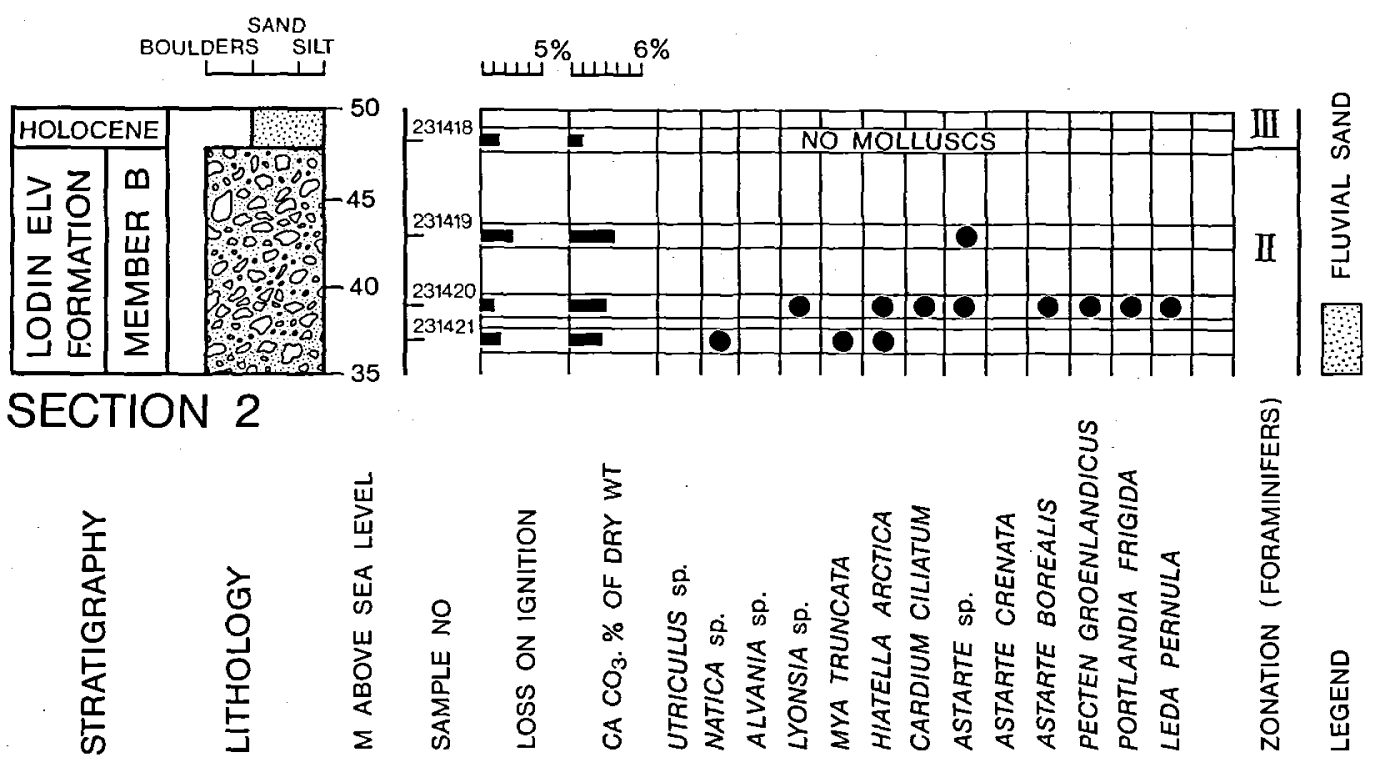

\section{SECTION 1}
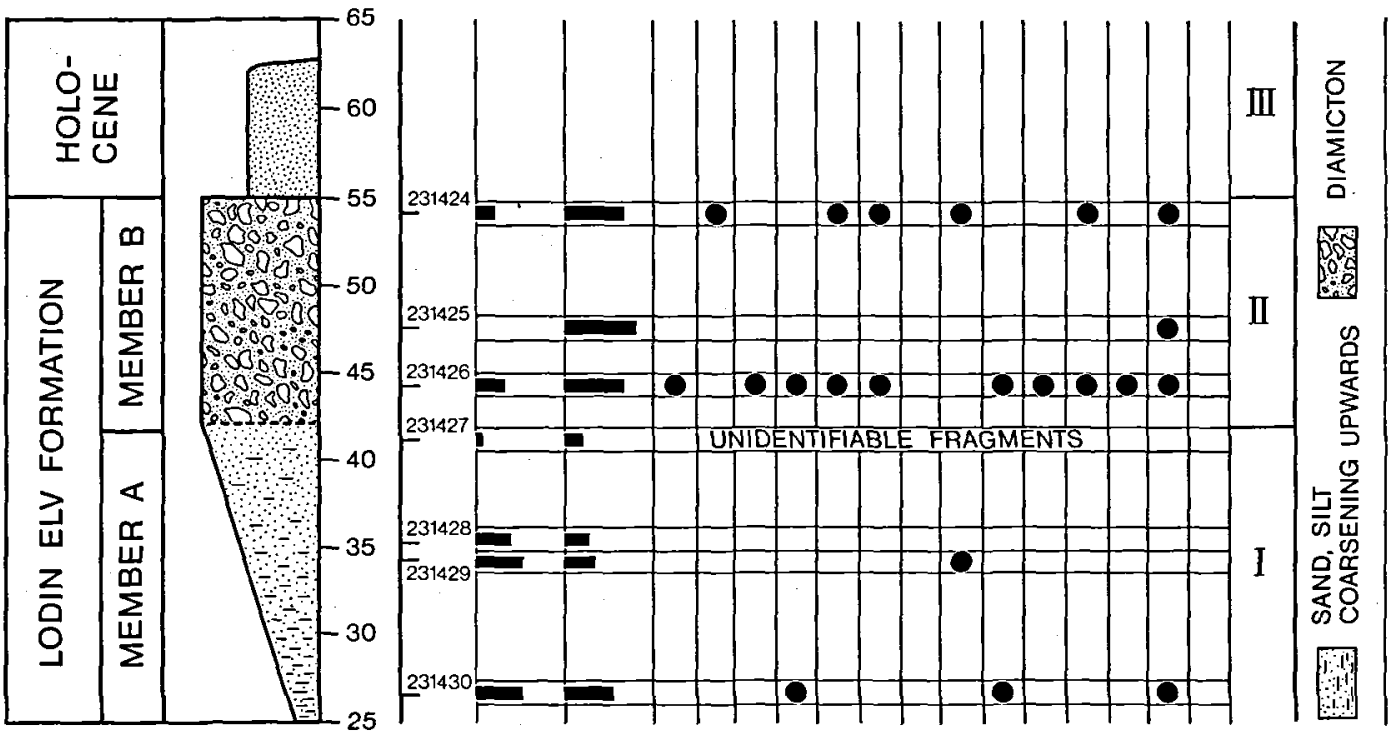

Fig. 11. Molluse faunas and sedimentary parametres in sections 1 and 2.

available information also the mollusc faunas associated with the Cassidulina teretis and Cibicides grossa zones at Clyde Foreland and the comparable zones $G$ and $H$ at Qivituq, Baffin Island, appear to be similar (Miller et al. 1977; Mode 1980; Nelson 1981).

\section{PLATE 5}

Fig. 1. The foraminiferal assemblage from GGU 231420, zone II, Lodin Elv Formation. Many Cassidulina cf. teretis. Fig. 2. The foreaminiferal assemblage of a sample $675 \mathrm{~m}$ below sea floor of a boring in the central North Sea at approximately $56^{1 / 2} 2^{\circ} \mathrm{N}$. Many Cassidulina cf. teretis. Fig. 3. The foraminiferal assemblage of a sample $925 \mathrm{~m}$ below sea floor of the same boring in the central North Sea. Note Cibicides grossa. 


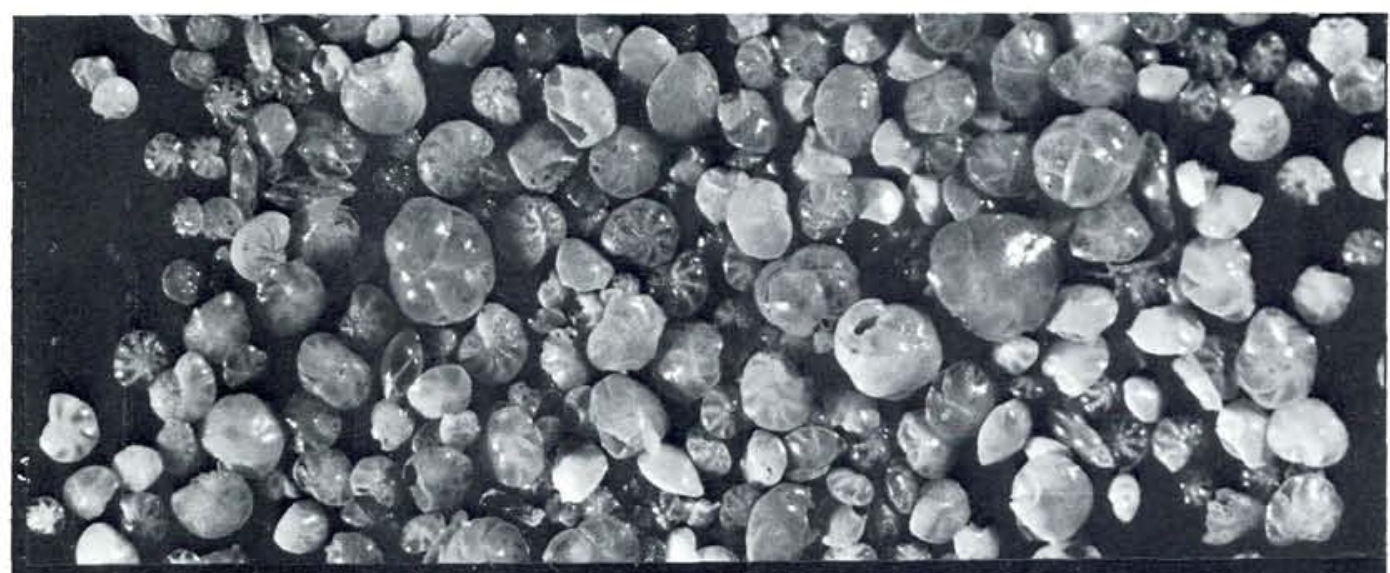

Fig. 1

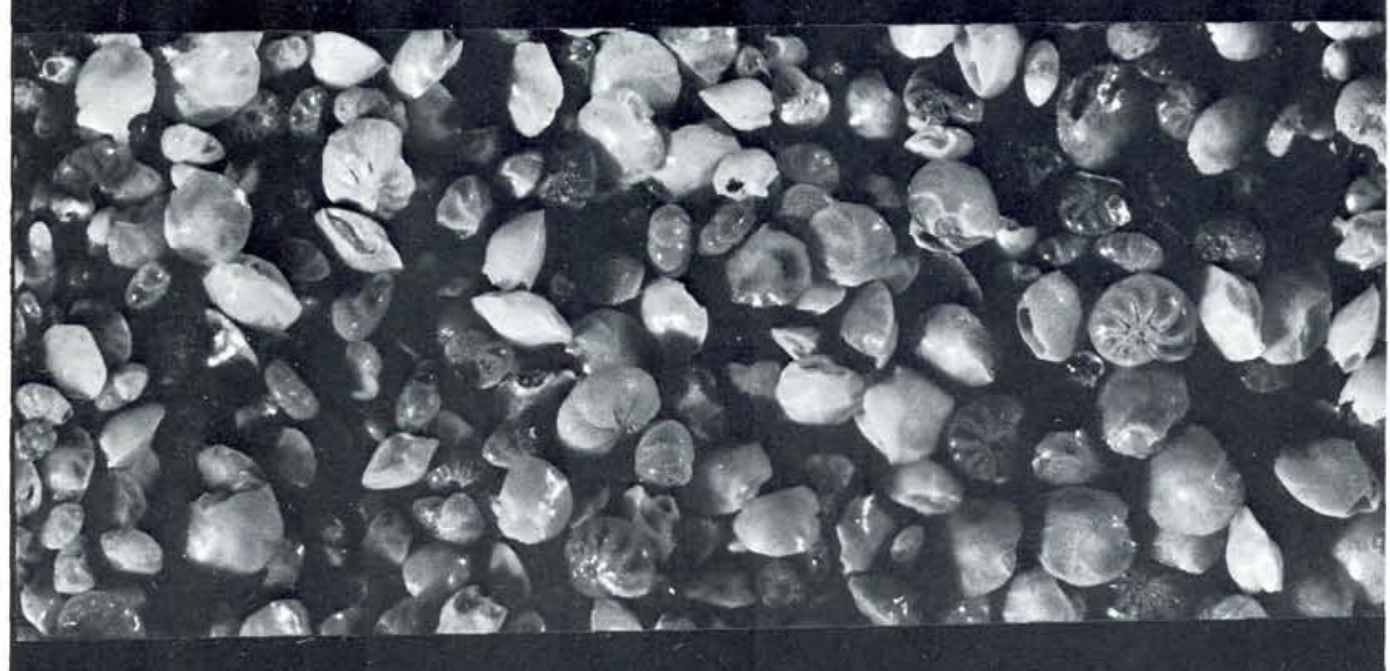

Fig. 2

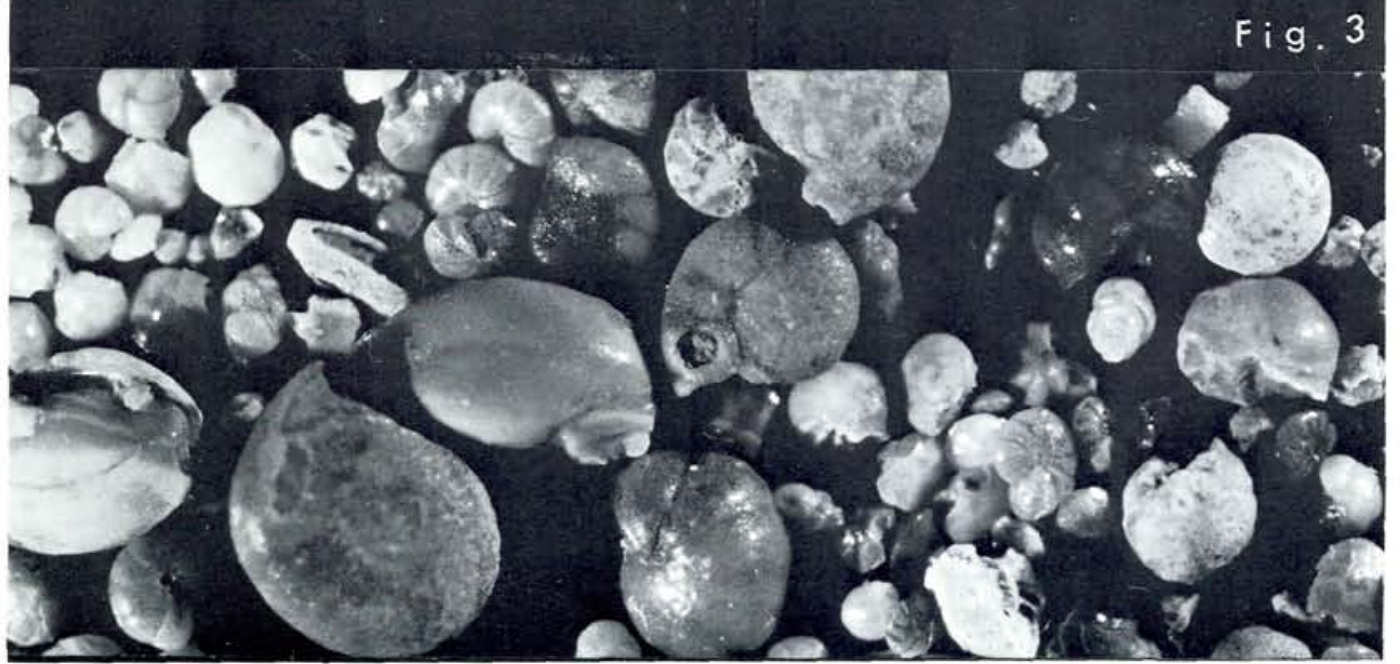



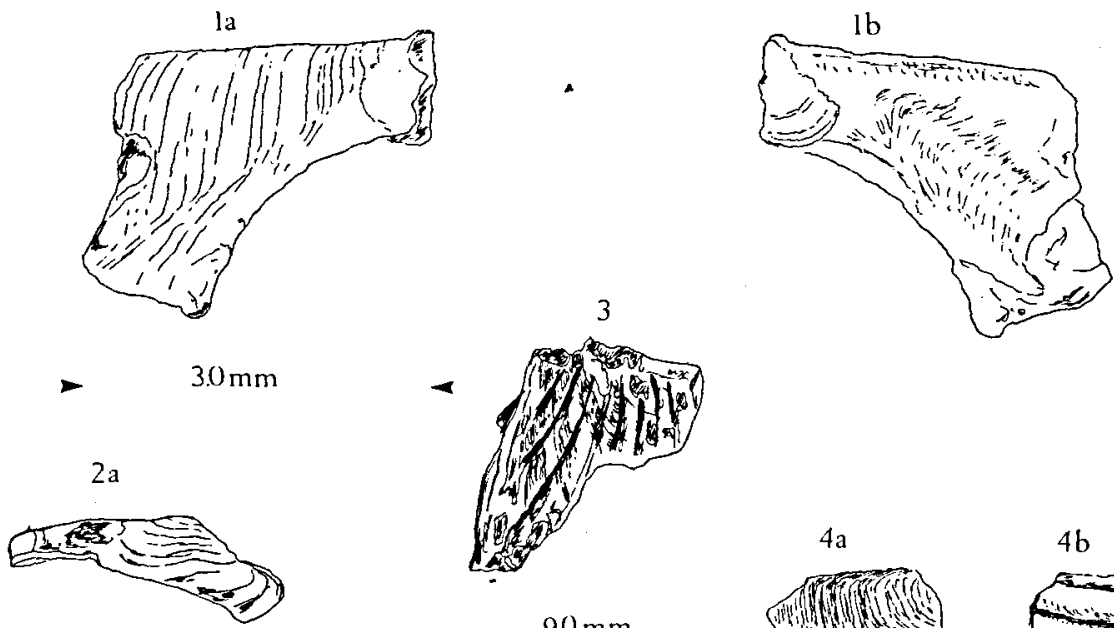

$2 \mathrm{~b}$

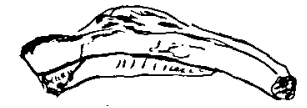

$6 a$
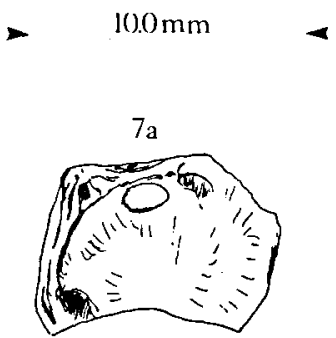

$7 b$
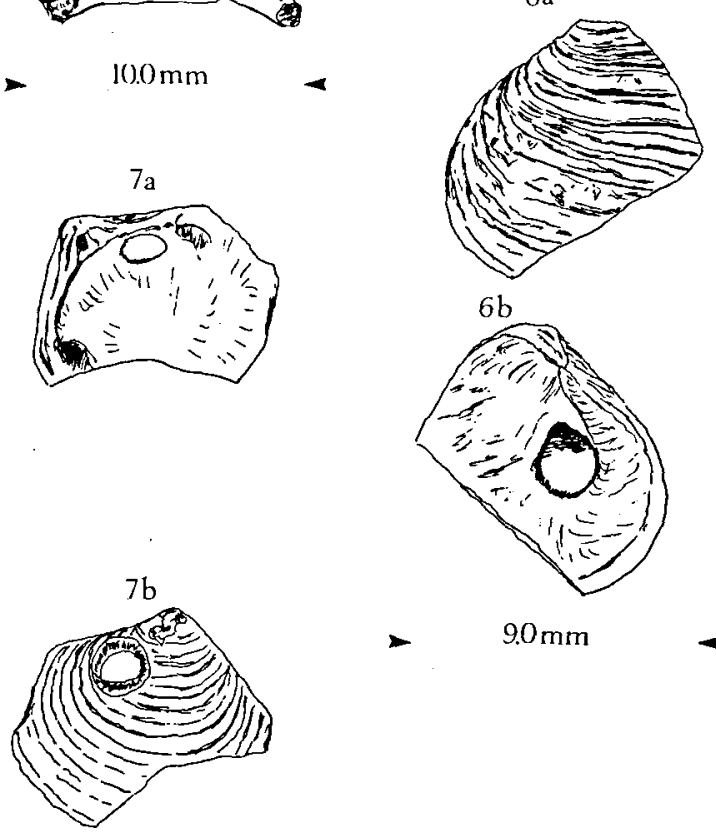

$6 \mathrm{~b}$

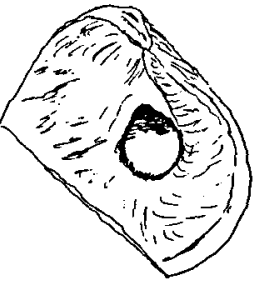

$9.0 \mathrm{~mm}$

$8 a$

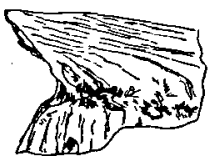

$9 b$

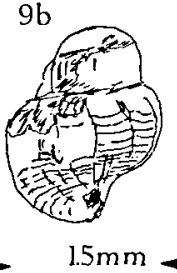

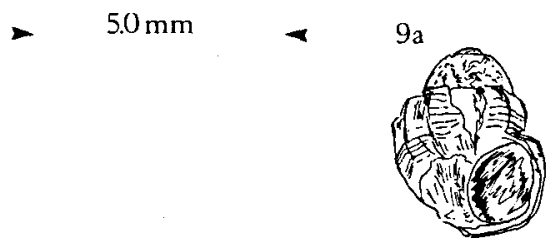
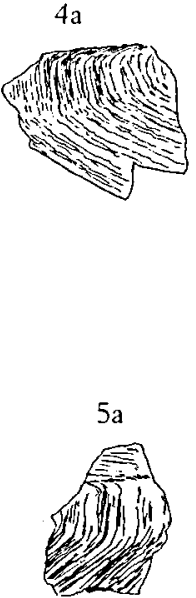

$5 b$

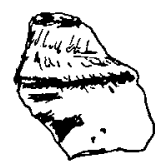

- $5.0 \mathrm{~mm}$

PLATE 6

Fig. 1a-b. Pecten groenlandicus Sowerby, fragment of right valve, MGUH 16032 from GGU 231424. Fig. 2a-b. Hiatella arctica (Linné), fragment of right valve, MGUH 16033 from GGU 231426. Fig. 3. Cardium ciliatum Fabricius, fragment of right valve, MGUH 16034 from GGU 231420. Fig. 4a-b. Leda pernula (O. F. Müller), fragment of posterior part of right valve, notice the strong inner carina, MGUH 16035 from GGU 231420. Fig. 5a-b. Leda pernula (O. F. Müller), fragment of posterior part of left valve, MGUH 16036 from GGU 231420. Fig. 6a-b. Hiatella arctica (Linné), fragment of left valve anterior part, MGUH 16037 from GGU 231420. Fig. 7a-b. Astarte borealis (Chemnitz), left valve with a borehole from a predatory gastropod, MGUH 16038 from GGU 231424. Fig. 8a-b. Hiatella arctica (Linné), fragment of left valve, MGUH 16039 from GGU 231420. Fig. 9a-b. Alvania sp., MGUH 16040 from GGU 231426. 
la

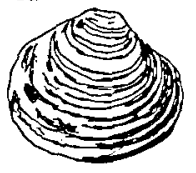

$3 a$

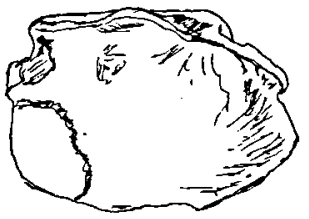

Ib

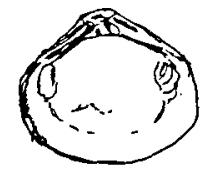

$-5.0 \mathrm{~mm}$
$2 a$

$2 b$

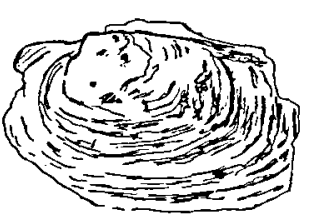

$20.0 \mathrm{~mm}$
$5 a$

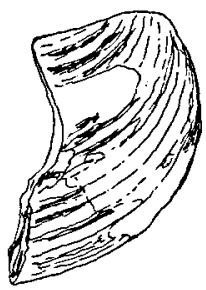

$5 \mathrm{~b}$

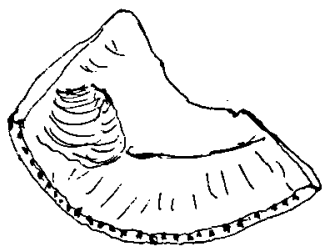

$10.3 \mathrm{~mm}$
$4 a$

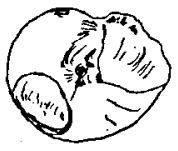

$6 a$

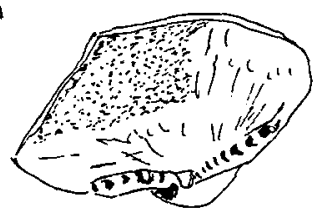

$4 b$

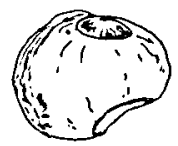

$-15 \mathrm{~mm}$

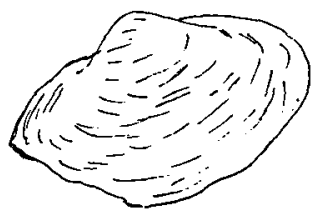

$-4.5 \mathrm{~mm}$

PLATE 7

Fig. 1a-b. Astarte sp., right valve, MGUH 16041 from GGU 231421. Fig. 2a-b. Utriculus sp., fragmentary specimen, MGUH 16042 from GGU 231426. Fig. 3a-b. Mya truncata Linné, fragmentary left valve of juvenile specimen, MGUH 16043 from GGU 231421. Fig. 4a-b. Natica sp., juvenile specimen with borehole from another predatory gastropod, MGUH 16044 from GGU 231421 . Fig. $5 \mathrm{a}-\mathrm{b}$. Astarte crenata (Gray), fragmentary specimen with periostracum partly perserved and crenulate margin, MGUH 16045 from GGU 231426. Fig. 6a-b. Portlandia frigida (Torell), right valve, MGUH 16046 from GGU 231420.

\section{Palynology}

The sediments contain pollen and spores, but so badly preserved that safe identification rarely is possible.

In GGU 231429, section 1 member A, two microscope slides yielded 162 grains of pollen and spores. 69 grains were uniden- tifiable, while 62 could be referred to saccate and triporate types, presumably of pre-Quaternary origin. The remaining 31 grains comprised Betula, Poaceae, Cyperaceae, Lycopodium, Polypodiaceae and Botrychium - types which are well represented in Holocene pollen spectra from the area (Funder 1978). Since the majority of the pollen and spores seem to be rebedded, little stratigraphical value can be attached to these results. 
Table 1

Amino acid ratios for three Hiatella arctica fragments from member B of the Lodin Elv Formation (Foraminifer zone II)

\begin{tabular}{lccc}
\hline GGU & & \multicolumn{2}{c}{ D-alloisoleucine : L-isoleucine } \\
No. & Lab. No. & Total fraction & Free fraction \\
\hline 231420 & AA1-1701 & $0.50,0.54$ & - \\
& & $0.50,0.50$ & 1.00 \\
& & $0.55,0.53$ & $0.90,0.97,0.93$ \\
\hline
\end{tabular}

\section{Amino acid diagenesis}

Three fragments of Hiatella arctica shells from member B, section 2, (Foraminiferal zone II) have been analysed for their amino acid diagenesis by G. H. Miller, University of Colorado. The shells were picked out from the sediment close to the permafrost surface. The results of the amino acid analyses appear from table 1 .

The parameter most significant for the age of the shells is the ratio of amino acids in the "total fraction", i.e. the acid hydrolysate of both free and peptide bound amino acids (e.g. Miller and Hare 1980), and the three shells show consistently high ratios of c. $\mathbf{0 . 5}$. These values are more than double as high as any of those from 60 other shells analysed from Jameson Land - or as any of the well over hundred ratios obtained from North and East Greenland - and indicate that the Lodin Elv Formation is considerably older than any other deposit in North and East Greenland from which amino acid data are available.

Unfortunately the amino acid ratios cannot be converted directly into ages. However, from a comparison with results from Alaska, Miller (pers.comm.) suggested $1 \mathrm{Ma}$ as a minimum age for the sample.

Admittedly, the results are too sparse to be regarded as definitive. However, the consistency of the measurements and the circumstance that "abnormally old" amino acid ratios occur together with an "abnormally old" foraminiferfauna give credence to the results.

The Cassidulina teretis zone at Clyde Foreland and the comparable foraminifer zone $G$ at Qivituq, Baffin Island, are characterized by amino acid ratios of $0.13-0.22$ in the total fraction (Mode 1980; Nelson 1981). Considering the similarity in the present climates of East Greenland and eastern Baffin Island, similarity in the rates of amino acid diagenesis in the two regions could have been expected. However, the lack of correlation between the two sets of amino acid data may indicate significant differences in the climatic histories in the two regions, or that faunas dominated by Cassidulina teretis cover a considerable time span.

\section{Conclusions and discussion}

The Lodin Elv Formation is an c. $40 \mathrm{~m}$ thick sequence of unconsolidated sediments probably resting on Lower Jurassic shale and covered by Holocene fluvial and deltaic deposits. Apparently it forms an erosional remnant of very local distribution at the mouth of Lodin Elv, Jameson Land.

The formation comprises two informal members. Member A, consisting of sand and silt with horizontal layering and $0.5 \mathrm{~m}$ thick beds of homogeneous silt, is interpreted as pro-deltaic. Member B, matrix supported silty diamicton with large erratic boulders, is interpreted as a subaqueous suspension sediment with an admixture of debris and boulders dropped from floating icebergs.

The presence of well-preserved foraminiferal faunas and marine molluscs testify to a marine origin of the formation. The mollusc faunas indicate a water depth of $25-50$ metres, in agreement with the evidence from the foraminifera, which further indicate that member $B$ was deposited in somewhat deeper water than member $\mathrm{A}$ - in accordance with the lithological development.

The presence of large boulders in member $B$ show that parts of the Scoresby Sund fjord complex were glaciated at the time when the sediments accumulated. Also the mollusc faunas, although poor in species, may indicate an arctic environment similar to the present. However, while the mollusc faunas indicate an arctic/high arctic environment, the evidence of the foraminiferal faunas suggests somewhat milder - boreal-arctic-conditions.

Conformably with the lithological division the formation is divided into two foraminiferal zones. Zone I, conforming with member A, is characterized by high frequencies of Cibicides grossa, and is by faunistic correlation referred to the Pliocene; while zone II, conforming with member $\mathrm{B}$, is characterized by high frequencies of Cas- 
sidulina cf. teretis, and is referred to the PliocenePleistocene transition. The faunistic dating is supported by an amino acid analysis of Hiatella arctica shells from member $\mathrm{B}$, foraminiferal zone II, indicating an unspecified high age for the deposit. The amino acid results show, however, that the deposit is considerably older than other deposits in East Greenland which has been tested with the amino acid method, and a minimum age of $1 \mathrm{Ma}$ for the shells was suggested by the amino acid laboratory.

On this evidence the Lodin Elv Formation is referred to the Pliocene and Lowest Pleistocenea period from which no other fossiliferous deposits have been recorded in Greenland. Thus the significance of the Lodin Elv Formation lies in the glimpse of light it throws on late Tertiary and early Quaternary environments and glaciation in Greenland.

The youngest Tertiary deposit hitherto known from Greenland is the Kap Brewster Formation, an isolated occurrence of clastic and fine-grained marine sediments exposed at the mouth of Scoresby Sund, c. 100 kilometres to the south of Lodin Elv (Birkenmajer 1972). The upper part of this formation, the "Chlamys beds", has on faunistic evidence been tentatively referred to the Miocene (Hassan 1953). The Chlamys beds have no species common with the modern Greenland marine fauna, and hold no evidence of arctic conditions.

The oldest fossiliferous Pleistocene deposits, on the other hand, are interglacial marine deposits on Jameson Land (Petersen 1982) and in West Greenland (Simonarson 1981). These deposits have tentatively been referred to the Eemian-Sangamonian Interglacial. Their mollusc faunas are distinctly arctic, and very similar to the modern fauna.

Hence, on the evidence from the Lodin Elv Formation the earliest known occurrence of arctic conditions and glaciation since Proterozoic times in Greenland can now be set at the Pliocene-Pleistocene transition.

Although interesting, this information is hardly surprising. On nearby northern Iceland "Glaciation down to sea level in the Tjörnes area is seen to have been reached about $2 \mathrm{Ma}$ although inland glaciations had been initiated more than one million years earlier". (Albertsson 1978:8), while the study of sediment cores from the Arctic
Ocean "... suggests that high latitude glaciation was under way $3 \mathrm{Myr}$ ag". (Herman \& O'Neil 1975:591).

It should finally be noted that an occurrence of clastic sediments, the Skeldal conglomerate, has earlier on the evidence of its clast-composition and lithification been referred to the Late Tertiary-Early Pleistocene period (Fränkl 1953). The Skeldal conglomerate occurs in an area near Kong Oscar Fjord c. 100 kilometres to the north of Lodin Elv.

Acknowledgements. We want to thank the following members of the staff at our institutes: Processing the samples: $H$. Bahnson and S. Meldgaard; photographs: S. Meldgaard, Irma and C. Torres; drawing of diagrams: Jette Gissel Nielsen, C. Rasmussen and Jannie Knudsen; typing the manuscript: Lissi Østerhaab and Birgit Nielsen who also read it critically. The field work was carried out for the Geological Survey of Greenland. The topographical base for figure 1 was drawn on the Survey's stereoplotter by O. Winding. S. Watt (Geological Survey of Greenland) kindly commented upon the text. The Director of the Survey is acknowledged for his permission to publish the results.

\section{Dansk sammendrag}

En ny marin forekomst af Plio-Pleistocæn alder fra Jameson Land, Østgrønland, beskrives som Lodin Elv Formationen. Lagpakken opbygges af velsorteret sand og silt overlejret af et diamikton indeholdende store erratiske blokke. Fra Lodin Elv Formationens to enheder optræder ialt 65 foraminifer arter, hvoraf den nedre (zone I) karakteriseres af Cibicides grossa og den ovre (zone II) af Cassidulina cf. teretis. 1 begge enheder findes mollusker in situ såsom Ledu pernula, Portlandia frigida og Astarte crenata. De fundne subfossile mollusker tilhører alle en fauna, som findes $\mathrm{i}$ det østgrønlandske fjordområde $\mathrm{i}$ dag.

Aflejringerne fremtræder som en erosionsrest med lokal udbredelse, hvilende på Jurassisk skifer og dækket af Holocane sand- og grussedimenter. Formationens tykkelse er omkring 40 meter. På basis af foraminiferfaunaerne korreleres aflejiringerne med forekomster i Nordsøen og på Baffin Island.

Aminosyre dateringer udført på molluskskaller (Hiatella arctica) støtter den aldersmæssige henforelse af aflejringen til overgangen mellem Pliocæn og Pleistocæn.

Lodin Elv Formationen udgor det tidligst kendte vidnesbyrd om glaciation og arktiske forhold på Grønland siden Eocambrium.

\section{References}

Albertsson, K. J. 1978: Um aldur jardlaga á Tjörnesi (Some Notes on the Age of the Tjörnes Strata Sequence, Northern Iceland). Náttúrufradingurinn 48, 1-8.

Bahnson, H., Petersen, K. Strand, Konradi, P. B. and Knudsen, K. L. 1974: Stratigraphy of Quaternary deposits in the Skrrumhede II boring: lithology, molluses and foraminifera. Danm. geol. Unders., Arbog 1973, 27-62.

Birkenmajer, K. 1972: Report on investigations of Tertiary sediments at Kap Brewster, Scoresby Sund, East Greenland. Rapp. Grenlands geol. Unders. 48, 85-91. 
Dam, T, and Reinhold, Th. 1941: Die stratigraphische Gliederung des niederländischen Plio-Pleistozäns nach Foraminiferen. Meded. geol. Sticht. C-5, 1, 66 pp.

Doppert, J. W. Chr. 1980: Lithostratigraphy and biostratigraphy of marine neogene deposits in the Netherlands. Meded. Rijks geol. Dienst 32-16, 255-311.

Doppert, J. W. Chr., Laga, P. G. and De Meuter, F. J. 1979: Correlation of the biostratigraphy of marine neogene deposits, based on benthonic foraminifera, established in Belgium and the Netherlands. Meded. Rijks Geol. Dienst, 31-1, 1-8.

Eiríksson, J. 1981: Lithostratigraphy of the upper Tjörnes sequence, North Iceland: The Breidavík Group. Acta Naturalia Islandica 29,37 pp.

Feyling-Hanssen, R. W. 1964: Foraminifera in Late Quaternary deposits from the Oslofjord area. Norges geol. Unders. 225,383 pp.

Feyling-Hanssen, R. W. 1972: The foraminifer Elphidium excavatum and its variant forms. Micropaleontology 18, 3, 337-354.

Feyling-Hanssen, R. W. 1976: The Clyde Foreland Formation, a micropaleontological study of Quaternary stratigraphy. 1st Int. Symp. on Benthonic Foraminifera of Continental Margins, Pt. B: Paleoecology and Biostratigraphy. Maritime Sediments, Spec. Publ. 1, 315-337.

Feyling-Hanssen, R. W. 1980a: Microbiostratigraphy of young Cenozoic marine deposits of the Qivituq Peninsula, Baffin Island. Marine Micropaleontology 5, 153-184.

Feyling-Hanssen, R. W. 1980b: An assemblage of Pleistocene foraminifera from Pigojoat, Baffin Island. Jour. Foram. Research 10, 266-285.

Feyling-Hanssen, R. W. 1981: Foraminiferal indication of Eemian interglacial in the northern North Sea. Bull. geol. Soc. Denmark 29, 175-189.

Feyling-Hanssen, R. W. Jørgensen, J. A., Knudsen, K. L. and Andersen, A.-L. L. 1971: Late Quaternary Foraminifera from Vendsyssel, Denmark and Sandnes, Norway. Bull. geol. Soc. Denmark 21 (2-3), 67-317.

FränkI, E. 1953: Die geologische Karte von Nord-Scoresby Land (NE-Grønland). Meddr Grønland 113, 6, $56 \mathrm{pp}$.

Friderichsen, J. D. and Bromley, R. G. 1974: Geological map sheet Gurreholm $71 \emptyset 2$ syd. Copenhagen: The geological Survey of Greenland.

Funder S. 1978: Holocene stratigraphy and vegetation history in The Scoresby Sund area, East Greenland. Bull. Gronlands geol. Unders. 129, $66 \mathrm{pp}$.

Funder, S. and Hjort, C. 1973: Aspects of the Weichselian chronology in central East Greenland. Boreas 2, 69-84.

Hassan, M. Y. 1953: Tertiary faunas from Kap Brewster, East Greenland. Meddr Gronland 111, 5, 42 pp.

Herman, Y. and O'Neil, J. R. 1975: Arctic palaeosalinities during late Cainozoic time. Nature 258, 591-595.

Jarke, J. 1961: Die Beziehungen zwischen hydrographischen Verhältnissen, Faziesentwicklung und Foraminiferenverbreitung in der heutigen Nordsee als Vorbild für die Verhältnisse während der Miocän-Zeit. Meyniana 10, 21-36.

King, C. 1980: Provisional microfaunal zonation - North Sea Cainozoic. In Report No. 6 (ed. R. Vinken, K.-J. Meyer) of "The N. W. European Tertiary Basin", I. G. C. P. Project 124, 42. Dec. 1980.

King, C., Bailey, H. W., King, A. D., Meyrick, R. W., Roveda, V. L., 1981: North Sea Cainozoic. In Jenkins, D. G. and Murray, J. W.: Stratigraphical atlas of fossil foraminifera. The British Micropalaeontological Society/Ellis Horwood Ltd, Chichester, 294-298.

Lorange, K. 1977: En mikropaleontologisk-stratigrafisk undersøkelse av kvartare sedimenter $i$ nordvestre del av Barentshavet. Unpubl. thesis, Geological Institute, University of Oslo, Norway, $237 \mathrm{pp}$.
De Meuter, F. J. and Laga, P. G. 1977: Lithostratigraphy and biostratigraphy based on benthonic foraminifera of the Neogene deposits of northern Belgium. Bull. Soc. belge Géol. 85 (4), 133-152.

Miller, G. H., Andrews, J. T. and Short, S. K. 1977: The last interglacial-glacial cycle, Clyde Foreland, Baffin Island, N. W. T.: stratigraphy, biostratigraphy and chronology Can. J. Earth Sci. 14, 2824-2857.

Miller, G. H. and Hare, P. E. 1980: Amino acid geochronology: integrity of the carbonate matrix and potential of molluscan fossils. In Hare, P. E., Hoering, T. C. and King, K. (eds): Amino acid biogeochemistry. 415-443. New York, John Wiley and Sons.

Mode, W. N. 1980:Quaternary stratigraphy and palynology of the Clyde Foreland, N. W. T., Canada. Unpubl. Ph. D. thesis, University of Colorado, $219 \mathrm{pp}$.

Nelson, A. R. 1981: Quaternary glacial and marine stratigraphy of the Qivitu Peninsula, northern Cumberland Peninsula, Baffin Island, Canada. Geol. Soc. Amer. Bull., Pt II, 22, 8, 1143-1261.

Ockelmann, W. K. 1958: Zoology of East Greenland marine lamellibranchiata, Meddr Grønland 122, $257 \mathrm{pp}$.

Petersen, K. Strand 1982: Attack by predatory gastropods recognized in an interglacial marine molluscan fauna from Jameson Land, East Greenland. Malacologia 22 (1-2), 721-726.

Sejrup, H.-P., Fjæran, T., Hald, M., Beck, L., Hagen, J., Miljeteig, I. and Norvik, O. 1981: Bethonic foraminifera in surface samples from the Norwegian continental margin between $62^{\circ} \mathrm{N}$ and $65^{\circ} \mathrm{N}$. Jour. Foram. Research 11 , 227-295.

Simonarson, L. A. 1981: Upper Pleistocene and Holocene marine deposits and faunas on the north coast of Nugssuaq, West Greenland. Bull Gronlands geol. Unders. $140,107 \mathrm{pp}$.

Thorson, G. 1934: Contributions to the animal ecology of the Scoresby Sound Fjord complex (East Greenland). Meddr Grønland 100, 3, $67 \mathrm{pp}$.

Tappan, H. 1951: Northern Alaska index foraminifera. Contributions from the Cushman Foundation for Foraminiferal Research 2, 1, 1-8.

Tood, R. 1957: Foraminifera from Carter Creek, northeastern Alaska. U. S. Geol. Survey, Prof. Pap. 294-F, 221-235.

Vilks, G. 1964: Foraminiferal study of East Bay, Mackenzie King Island, District of Franklin (Polar Continental Shelf Project). Geol. Surv. Canada, Paper no. 64-53, 26 pp.

Vilks, G. 1969: Recent foraminifera in the Canadian Arctic. Micropaleontology 15, 1, 35-60.

Vilks, G., Wagner, F. J. E. and Pelletier, B. R. 1979: The Holocene marine environment of the Beaufort shelf. Geol. Surv. Canada, Bull. 303, 43 pp.

Voorthuysen, J. H. van 1950: The quantitative distribution of the Plio-Pleistocene Foraminifera of a boring at the Hague (Netherlands). Meded. geol. Sticht., N. S. 4, 31-49.

Voorthuysen, J. H. van, Toering, K. and Zagwijn, W. H. 1972: The Plio-Pleistocene boundary in the North Sea basin, revision of its position in the marine beds. Geologie en Mijnbouw, 51 (6), 627-639.

\section{Appendix}

A total of 65 species of foraminifera occurred in the investigated samples of the Lodin Elv Formation. Some of them are listed here, and a few remarks added.

Quinqueloculina agglutinata Cushman

1917, U. S. Nat. Mus., Bull. 1, pt. 6, p. 43, pl. 9, fig. 2.

Occurred in zone I. 
Quinqueloculina arctica Cushman

1933, Smithsonian Misc. Coll. 89, No. 9, p. 2, pl. 1, figs. 3 a-c. Observed in zone II.

Quinqueloculina borea Gudina

Pl. 1., fig. 1.

1966, Akad. Nauk SSSR, Sibirskoje Otd., Inst. Geol. Geofiz., Moscow, p. 23, pl. 1, figs. 2-3.

Observed in zone II.

Quinqueloculina longa Gudina

1969, Akad, Nauk SSSR, Sibirskoje Otd., Inst. Geol. Geofiz. 63, p. 9, pl. 2, figs. 2-4.

Observed in zone II.

Quinqueloculina seminulum (Linné)

1758 Serpula seminulum Linné: Systema naturae. Ed. 10. Lipsia 1 , p. 786 , pl. 2 , fig. 1 .

Occurred in zone $I$ and II.

Quinqueloculina stalkeri Loeblich and Tappan

1953, Smithsonian Misc. Coll. 121, No. 7, p. 40, pl. 5, figs. 5-9.

Present in zone 1.

Dentalina baggi Galloway and Wissler

Pl. 1, fig. 5

1927, Jour Paleont. 1, p. 49, pl. 8, figs. 14, 15.

Observed in zone I and II.

Dentalina ittai Loeblich and Tappan

Pl. 1, fig. 4

1953, Smithsonian Misc. Coll. 121, No. 7, p. 56, pl. 10, figs. 10-12.

Observed in zone $\mathrm{I}$ and II.

Guttulina dawsoni Cushman and Ozawa

P1. 1., fig. 2.

1930, U. S. Nat. Mus., Proc. 77 (6), p. 47, figs. 1, 2.

Occurred in zone II.

\section{Guttulina lactea (Walker and Jacob)}

1798 Serpula lactea Walker and Jacob, in Adams, G.: Essays on the Microscope. Kanmacher. (2nd ed.), p. 634, pl. 14, fig. 4 .

Occurred in 2 samples of zone I and 3 of zone II.

Guttulina problema (d'Orbigny)

PI. 1, fig. 3

1826 Polymorphina problema d'Orbigny: Ann. Sci. nat. Paris ser. 1 , vol. 7 , p. 266 , no. 61 .

Occurred in zone II.

Sigmoidella pacifica Cushman and Ozawa

1928, Cushaman Lab. Foram. Res., Contr. 4, pt. 1, p. 19, pl. 2, fig. 13.

Occurred in zone I.

\section{Glandulina laevigata d'Orbigny}

Pl. 1, fig. 20

1826 Nodosaria (Glandulina) laevigata d'Orbigny: Ann. Sci nat.

Paris ser. 1, vol. 7, p. 252, pl. 10, figs. 1-3.

Occurred in two samples of zone I and two of zone II. This species should probably be referred to Tappanella arctica Gudina and Saidova, 1969

The Genera Oolina and Fissurina were poorly represented in both zones of the Lodin Elv Formation.
Stainforthia loeblichi (Feyling-Hanssen)

Pl. 1, fig. 14

1954 Virgulina loeblichi Feyling-Hanssen: Norsk geol. Tidsskr. 33 , p. 191 , pl. 1 , figs. $14-18$, text-fig. 3 .

Occurred in 9 samples of the Lodin Elv material, reaching a frequence of $9 \%$ in the uppermost part of zone II.

\section{Stainforthia schreibersiana (Czjzek)}

Pl. 1, fig. 16

1848 Virgulina schreibersiana Czjzek: Haidinger's Nat. wiss. $A b h .2$, p. 147, pl. 13, figs. 18-21.

Very rare, in the upper part of zone II.

\section{Angulogerina fluens Todd}

Pl. 1, fig. 15

1947, Cushman Lab. Foram. Res., Contr. 23, pt. 3, p. 67, pl. 16 , figs. 6-7.

Occurred in one sample of zone I and four of zone II.

\section{Cassidulina reniforme Nørvang}

Pl. 1 , fig. 10

1945 Cassidulina crassa d'Orbigny, var. reniforme Nørvang: The zoology of Iceland, Foram. Munksgaard (Copenhagen and Reykjavik) 2 (2), p. 41, text-figs. 6 c-h. Cassidulina subacuta Gudina - Feyling Hanssen, 1976, Arctic and Alpine Res., vol. 8, No. 2, p. 176; Maritime Sediments Spec. Pub. 1, p. 354, pl. 2, figs. 14-19; 1980, Marine Micropaleontology, vol. 5, p. 180, pl. 4, figs. 12-14.

More frequent in zone II than in zone I of the Lodin Elv Formation. Its maximum frequency was $7 \%$.

Cassidulina cf teretis Tappan

Pl. 1, figs. 6-9, 11-13

1951 Cassidulina teretis Tappan: Cushman Found. Foram. Res., Cont. 2, pt. 1, p. 7, pl. 1, fig. 30.

Under this taxon is grouped typical Cassidulina teretis (e.g. pl. 1, fig. 9, cf. Feyling-Hanssen, 1976, pl. 1, fig. 13; pl. 2, figs. $20-21$ and Feyling-Hanssen 1980, pl. 4, figs. 10,11 and 15) and deviating forms as illustrated in pl. 1, figs. 6-8 and 11-13.

Cassidulina cf. teretis is abundant in all the fossiliferous samples of the Lodin Elv Formation, both of zone I and zone II. Its lowest frequency was $20 \%$ (in sample no. 231428 of zone I), its highest $52 \%$ (sample no. 231421 of zone II). It characterizes zone II.

Islandiella helenae Feyling-Hanssen and Buzas

1976, Journ. of Foram. Res. 6 (2), p. 156, figs. 1-4.

It occurred in one sample of zone I, $231429(<1 \%)$, and one of zone II, $231420(1 \%)$.

Islandiella inflata (Gudina)

1966 Cassidulina inflata Gudina: Akad. Nauk SSSR, Sibirskoje Otd., Inst. Geol. Geofiz., Moscow, p. 63, pl. 6, figs. 4-6; pl. 7, fig. 1.

One specimen in sample no. 231428 of zone $I$.

Islandiella islandica (Nørvang)

PI. 1, figs. 17-19

1945, Cassidulina islandica The zoology of Iceland, Foram. Munksgaard (Copenhagen and Reykjavik) 2 (2), p. 42, fig. 7.

Occurred in zone II where it attained $3 \%$ of the assemblage in sample no. 231421 and $1 \%$ in no 231420 .

Islandiella norcrossi (Cushman)

1933 Cassidulina norcrossi Cushman: Smithsonian Misc. Coll. 89 , no. 9 , p. 7 , pl. 2 , fig. 7 .

Occurred in three samples of zone II. 
Buccella frigida (Cushman)

Pl. 2, figs. 4-6

1922 Pulvinulina frigida Cushman: Canadian Biol., 1921 (1922), p. 12 (144).

A few specimens in two samples of zone I and two of zone II.

Buccella hannai arctica Voloshinova

1960 Buccella hannai (Phleger and Parker), subsp. arctica Voloshinova: Mikrofauna SSSR, Sb. 11, VNIGRI 153, p. 286, pl. 8, figs. 2-4.

Occurred in one sample of zone I and three of zone II.

Epistominella vitrea Parker

Pl. 2, figs. 7, 8

1953, Cushman Found. Foram. Res., Spec. Publ. 2, p. 9, pl. 4, figs. 34-36, 40-41.

Frequent in all fossiliferous samples of the Lodin Elv Formation. In sample no. 231426 it accounted for $31 \%$ of the foraminiferal assemblage.

Cibicides grossa Ten Dam and Reinhold

Pl. 2, figs. 9-11, 14-16

1941 Cibicides lobatulus (Walker and Jacob) var. grossa Ten Dam and Reinhold: Med. Geol. Sticht., ser. CV (1), p. 62, pl. 5, fig. 5; pl. 6, fig. 1. Feyling-Hanssen, 1980, Marine Micropal. 5, p. 164 , pl. $V$, figs. $1-3,4-6$.

Frequent in the three fossiliferous samples of zone I ( $21 \%$ in sample no. 231430). Single specimens observed in four samples of zone II.

Cibicides lobatulus (Walker and Jacob)

PI. 2, figs. 1-3

1798 Nautilus lobatulus Walker and Jacob, in Adams, G.: Essays on the Microscope. Kanmacher. Ed. 2, London, p. 642, pl. 14 , fig. 36.

A few specimens present both in zone I and zone II.

Nonion cf. barleeanum (Williamson)

Pl. 2, figs. 12, 13; Pl. 3, figs. 5-8

1858 Nonionina barleeanum Williamson: Ray Society, London, p. 32, pl. 3, figs. 68,69 .

The specimens from the Lodin Elv Formation are thicker than the specimen figured by Williamson, they have also fewer chambers. In an evolutinary series (Todd, 1957) they might be placed somewhere between Nonion erucopsis Todd (1953, U.S. Geol. Survey, Prof. Pap. 294-F, p. 231, pl. 28, fig. 15, cf. present paper pl. 2, figs. 12, 13 and pl. 3, fig. 5 with few chambers and narrow umbilicus) and Nonion affine (Reuss, 1851, Nonionina affinis Reuss, Zschr. Deu. Geol. Ges., vol. 3, p. 72, pl. 5. fig. 32 with limbate sutures and wider umbilicus, cf. pl. 3, fig. 8 of the present paper). The specimen of pl. 3, figs. 6,7, comes closest to Nonion barleeanum.

Nonion labradoricum (Dawson)

Pl. 3, figs. 1, 2

1960Nonionina labradorica Dawson: Canadian Nat. 5, p. 191, fig. 4.

Single specimens in two samples of zone II.
Nonion orbiculare (Brady)

Pl. 3, figs. 3, 4

1881 Nonionina orbicularis Brady: Ann. Mag. Nat. Hist. London, ser. 5 , vol. 8 , p. 415 , pl. 21 , fig. 5 .

Occurred in all the fossiliferous samples of the Lodin Elv Formation, most frequent in sample no. 231429 of zone I where it made $12 \%$ of the assemblage. The specimens are more compressed than many Recent and Upper Quaternary forms. They resemble a specimen figured by Doppert $(1980$, pl. 4 , figs. 2 a, b) from Upper Pliocene / Lower Pleistocene of the Netherlands.

Elphidium albiumbilicatum (Weiss)

Pl. 3, figs. 9, 10

1954 Nonion pauciloculum Cushman, subsp. albiumbilicatum

Weiss, U.S. Geol. Surv., Prof. Pap. 254-G, p. 157, pl. 32, figs 1, 2.

Rare, occurred in one sample of zone I and in four of zone II.

Elphidium asklundi Brotzen

Pl. 3, figs. 13, 14

1943 Bull. geol. Inst. Uppsala 31, p. 267, figs 109-1.

A few specimens in zone II.

Elphidium bartletti Cushman

PI. 3, fig. 19

1933, Smithsonian Misc. Coll. 89, no. 9, p. 4, pl. 1, fig. 9.

$\mathrm{A}$ few specimens in all the samples of zone II.

Elphidium excavatum (Terquem)

Pl. 3, figs. 15-18

1875 Polystomella excavata Terquem: Essay sur le Classement des Animaux qui vivent sur le Plage et dans les environs de Dunkerque, Pt. 1, Paris, p. 25, pl. 2, fig. 2.

Frequent in most samples of the Lodin Elv Formation, reaching a mximum of $33 \%$ in sample 231426 of zone II. Most specimens in the present material belong to forma clavata Cushman (Pl. 3, figs. 17, 18), but forma selseyensis (Heron-Allen and Earland) and alba Feyling-Hanssen (P1. 3, figs. 15, 16) also occur.

Elphidium groenlandicum Cushman

1933, Smithsonian Misc. Coll. 89, no. 9, p. 4, pl. 1, fig. 10.

Observed in zone II.

Elphidium subarcticum Cushman

1944, Cushman Lab. Foram. Res., Spec. Publ. 12, p. 27, pl. 3, figs. 34,35 .

A few specimens in zone II.

Elphidium ustulatum Todd

Pl. 3, figs. 11, 12

1957, U.S. Geol. Surv., Prof. Pap. 294-F, p. 230, pl. 28, fig. 16.

A few specimens in most of the samples from the Lodin Elv Formation. 